\title{
Principios y derechos fundamentales de los trabajadores en Colombia, inclusión en tratados de libre comercio y breve comparación con los de otros países iberoamericanos*
}

Fundamental principles and rights of workers in Colombia, inclusion in free trade agreements and a brief comparison between those of other Ibero-American countries

\section{Diana María Gómez Hoyos**}

\section{RESUMEN}

En este trabajo se exponen los principios y derechos fundamentales del trabajo en Colombia y su referencia en los tratados de libre comercio que ha celebrado, como también se documentan aquellos que conocen dichos temas en otros paises iberoamericanos. Lo anterior se complementa con un anexo que contiene un cuadro sobre los dieciocho tratados de libre comercio que contemplan asuntos laborales en la región.

PALABRAS CLAVE: Tratados de libre comercio, principios y derechos fundamentales del trabajo, derecho de asociación sindical y negociación colectiva, trabajo forzoso u obligatorio, trabajo infantil, discriminación.

\begin{abstract}
This paper presents the principles and rights at work in Colombia and its reference in the free trade agreements, as also documents those handling such issues in other iberoamerican countries. This is complemented with an annex containing a picture of 18 free trade agreements that include labour issues in the region.
\end{abstract}

KEY WORDS: Free trade agreements (FAS), principles and rights at work, right to unionise and collective bargaining, forced labour, child labour, discrimination.

\footnotetext{
* Recibido: 8 de febrero de 2013. Aceptado: 27 de marzo de 2013.

* Profesora de Derecho laboral individual y colectivo en la Universidad de La Sabana, Colombia. (diana.gomez@unisabana.edu.co).
} 


\section{Sumario}

1. Introducción

2. Generalidades

3. Principios y derechos fundamentales de los trabajadores en Colombia

A) Libertad de asociación, libertad sindical y reconocimiento efectivo del derecho de negociación colectiva

B) Eliminación de todas las formas de trabajo forzoso u obligatorio

c) Abolición efectiva del trabajo infantil

D) Eliminación de la discriminación en materia de empleo y ocupación

4. Tratados de libre comercio celebrados por Colombia con Canadá, Chile y Estados Unidos

5. Tratados de libre comercio en otros paises de lberoamérica, y su comparación en asuntos laborales con los suscritos por Colombia

6. Conclusiones

\section{Introducción}

De forma persistente se comenta que "la unión hace la fuerza", y ello es lo que precisamente sucede con los tratados de libre comercio (TLCS), las uniones aduaneras, los acuerdos comerciales (Acs), los acuerdos de libre comercio (ALCS) o acuerdos de promoción comercial (APCS), los mercados comunes y, en general, todas aquellas formas que tienen como objetivo mejorar el comercio y permitir la libre circulación de personas y de mercancías. Lo anterior enmarca el concepto de "integración económica", cuya esencia es la "ausencia de fronteras y de obstáculos comerciales”, ausencia que resulta necesaria en el escenario de globalización e internacionalización que el mundo vive.

En tratándose de ACS o TLCS, no siempre en ellos se han incluido cuestiones laborales. Y respecto a los países iberoamericanos, solamente dieciocho acuerdos o tratados, de los más de setenta que se han suscrito, contienen clausulado, acuerdos complementarios, memorándums, mecanismos de cooperación laboral o anexos referidos a asuntos del trabajo.

La Comisión Mundial sobre la Dimensión Social de la Globalización señaló en 2004 que "[...] las reglas que rigen la economía global deberían destinarse a mejorar los derechos, los medios de subsistencia, la seguridad y las oportunidades para las personas, las familias y las comunidades en todo el mundo".

Las reglas de la economía global en los últimos años están siendo dadas por TLcs, que se celebran para mejorar la situación económica y social de los países

\footnotetext{
${ }^{1}$ Comisión Mundial sobre la Dimensión Social de la Globalización. Informe por una globalización justa: crear oportunidades para todos, Ginebra, 2004, p. 159.
} 
que los suscriben, máxime si uno de los firmantes es una nación subdesarrollada. Esos derechos, medios de subsistencia y oportunidades pueden perfeccionarse si no se olvida que "la paz universal permanente sólo puede basarse en la justicia social”, como lo tiene establecido la Organización Internacional del Trabajo (en adelante oıт) desde sus orígenes en el primer párrafo del preámbulo de su Constitución. ${ }^{2}$

El concepto de justicia social tiene sus comienzos en el siglo xIx y está relacionado con la "cuestión social" a la cual hace referencia la Encíclica Rerum Novarum $^{3}$ ante la situación de pobreza de los obreros y la acumulación de riquezas en pocas manos. Se mencionan como deberes de justicia por parte del obrero, "cumplir con lo que por propia libertad y con arreglo a la justicia se haya estipulado sobre el trabajo, no dañar en modo alguno al capital, no ofender a la persona de los patronos, abstenerse de toda violencia al defender sus derechos y no promover sediciones [...]", entre otros. Y por parte del patrono, "no considerar a los obreros como esclavos, respetar en ellos, como es justo, la dignidad de la persona, sobre todo ennoblecida por lo que se llama el carácter cristiano", y se añade que "lo realmente vergonzoso e inhumano es abusar de los hombres como de cosas de lucro". Recuerda que entre los principales deberes de los patronos está el dar a cada uno lo que sea justo.

Señala John Rawls “que un Estado será justo cuando sus ciudadanos estén preparados para afirmar una serie de principios característicos que permitan asignar derechos y deberes básicos a cada persona y determinar cuál es la distribución apropiada de los beneficios y las cargas de la cooperación social".

El autor menciona como libertades básicas (que no son absolutas):

a) La libertad política y la libertad de expresión y de reunión.

b) La libertad de conciencia y de pensamiento.

c) La libertad de la persona, que incluye la libertad frente a la opresión psicológica, la agresión física y la integridad.

d) El derecho a la propiedad personal.

100 e) La libertad respecto al arresto y detención arbitrarios, tal y como está definida por el concepto de Estado de derecho. ${ }^{5}$

\footnotetext{
2 Véase olт. Constitución, disponible en: http://www.ilo.org/dyn/normlex/es/f?p=1000:62:0::No::P62_LIST_ENTRIE_ ID:2453907 [En línea]. [Citado: 5. Enero. 2013].

${ }^{3}$ León XIII. Carta Encíclica Rerum Novarum "Sobre la situación de los obreros", 15 de mayo de 1891.

${ }^{4}$ Rawls, John. Teoría de la justicia, Fondo de Cultura Económica, México, 2002, p. 5.

${ }^{5}$ Véase Rawls, John. Justicia como equidad. Materiales para una teoría de la justicia, Tecnos, Madrid, 2002, pp. 172 y 177.
} 


\section{Generalidades}

Es interesante mencionar que el primer tratado escrito del cual se tiene noticia es el Tratado de Kadesh, concluido entre los hititas y los egipcios en el 1279 a.c. (Museo Arqueológico de Estambul). ${ }^{6} \mathrm{Y}$ el primer TLc es el franco-británico de libre comercio (o Tratado de Cobden-Chevalier) firmado en 1860. Marcus Lampe, citado por Cerón Coral, expresa que "la firma de este Tratado inició una «epidemia de libre comercio" en Europa que dio fin a siglos de protección"?

lberoamérica la componen diecinueve países, más Puerto Rico, ${ }^{8}$ y de ellos, todos hacen parte de la olT, organismo al cual ingresaron en diversos años: desde sus orígenes (1919) están Argentina, Bolivia, Brasil, Chile, Colombia, Cuba, El Salvador, Guatemala, Honduras, Nicaragua, Panamá, Paraguay, Perú, Uruguay y Venezuela. Luego se fueron afiliando Costa Rica, República Dominicana, México, Ecuador y Estados Unidos (del que hace parte Puerto Rico). ${ }^{9}$

Entre las funciones de la oit está la de adoptar las normas internacionales del trabajo (NIT), bien sea en forma de convenios (con carácter vinculante) o de recomendaciones.

En 1944, ya la oाт contemplaba principios y derechos que estaban consagrados en su Constitución y en la Declaración de Filadelfia, ${ }^{10}$ los que han servido de base para el posterior desarrollo de los principios y derechos fundamentales en el trabajo:

1) El trabajo no es una mercancía.

2) La libertad de expresión y de asociación es esencial para el progreso constante.

3) La pobreza, en cualquier lugar, constituye un peligro para la prosperidad de todos.

4) La lucha contra la necesidad debe proseguirse con incesante energía dentro de cada nación y mediante un esfuerzo internacional continuo y concertado, en el cual los representantes de los trabajadores y de los empleadores,

\footnotetext{
${ }^{6}$ Cerón Coral, Jaime. La incidencia jurídica laboral en Colombia del Tratado de Libre Comercio con Estados Unidos, trabajo presentado para su ascenso a miembro de número en la Academia Colombiana de Jurisprudencia, 24 de septiembre de 2012, p. 2.

7 Lampe, Marcus. "Explaining Nineteenth-Century Bilateralism: Economic and Political Determinants of the CobdenChevalier Network", en Economic History Review, 2010, p. 1.

${ }^{8}$ Estado libre asociado de Estados Unidos, pero no incorporado.

${ }^{9}$ Véase http://www.lo.org/dyn/normlex/es/f?p=1000:11003:0::No::.: [En línea]. [Citado: 21. Diciembre. 2012].

${ }^{10}$ огт. Declaración de Filadelfia sobre los fines y objetivos de la OIT, Conferencia General, 26a. Reunión, 10 de mayo de 1944, disponible en: http://www.lo.org/dyn/normlex/es/f?p=1000:62:0::No::P62_LIST_ENTRIE_ID:2453907 [En línea]. [Citado: 23. Octubre. 2012].
} 
colaborando en un pie de igualdad con los representantes de los gobiernos, participen en discusiones libres y en decisiones de carácter democrático, a fin de promover el bienestar común.

Conforme a su Constitución, ${ }^{11}$ cada Estado miembro se obliga a someter el Convenio respectivo, en el término de un año, a la autoridad correspondiente de su país para darle forma de ley o para adoptar "otras medidas".

Sin embargo, en 1998 la oाт profirió una Declaración Relativa a los Principios y Derechos Fundamentales en el Trabajo, ${ }^{12}$ en la que establece que aunque los Estados no hayan ratificado los convenios sobre principios y derechos enunciados en su Constitución y en la Declaración de Filadelfia, tienen el compromiso -que se deriva "de su mera pertenencia a la Organización"- de "respetar, promover y hacer realidad, de buena fe y de conformidad con la Constitución, los principios relativos a los derechos fundamentales que son objeto de esos convenios", es decir:

a) La libertad de asociación y la libertad sindical, y el reconocimiento efectivo del derecho de negociación colectiva.

b) La eliminación de todas las formas de trabajo forzoso u obligatorio.

c) La abolición efectiva del trabajo infantil.

d) La eliminación de la discriminación en materia de empleo y ocupación.

La Declaración tiene como objetivo principal la promoción de los cuatro principios y derechos fundamentales que, se considera, son las "bases mínimas para que el progreso social acompañe el progreso económico y el desarrollo”, haciéndose énfasis en que no solamente se predican de los trabajadores subordinados o dependientes, sino también de trabajadores independientes, y por ello son, a la vez, el cimiento del trabajo decente.

Entonces, están enmarcados necesariamente en el concepto de "trabajo decente y productivo" que, en las Memorias de la 87a. Conferencia Internacional del Trabajo de 1999, se propuso como finalidad primordial de la orт, en condiciones de libertad, equidad, seguridad y dignidad humana, punto de partida de los cuatro objetivos estratégicos de la оाт: promoción de los derechos fundamentales en el trabajo, empleo, protección social y diálogo social. ${ }^{13}$

\footnotetext{
11 Véase http://www.ilo.org/dyn/normlex/es/f?p=1000:62:0::No::P62_LIST_ENTRIE_ID:2453907 [En línea]. [Citado: 5. Enero. 2013].

12 оाт. Declaración relativa a los principios y derechos fundamentales en el trabajo y su seguimiento, Conferencia Internacional del Trabajo, 86a. Reunión, 18 de junio de 1998, disponible en: http://www.ilo.org/declaration/ thedeclaration/textdeclaration/lang--es/index.htm [En línea]. [Citado: 22. Octubre. 2012].

${ }^{13}$ огт. Memorias sobre trabajo decente, 87a. Conferencia Internacional del Trabajo, 1999, p. 12, disponible en: http:// www.ilo.org/public/libdoc/ilo/P/09651/09651(1999-87).pdf [En línea]. [Citado: 17. Septiembre. 2012].
} 
En la Declaración, la ort recuerda que esos principios y derechos fundamentales han sido expresados y desarrollados en forma de derechos y obligaciones específicos en convenios que han sido reconocidos como fundamentales dentro y fuera de la оाт: el 29 sobre el Trabajo Forzoso, ${ }^{14}$ el 87 sobre la Libertad Sindical y la Protección del Derecho de Sindicación, ${ }^{15}$ el 98 sobre el Derecho de Sindicación y de Negociación Colectiva, ${ }^{16}$ el 100 sobre Igualdad de Remuneración, ${ }^{17}$ el 105 sobre la Abolición del Trabajo Forzoso, ${ }^{18}$ el 111 sobre la Discriminación en el Empleo y la Ocupación, ${ }^{19}$ el 138 sobre la Edad Mínima, ${ }^{20}$ y el 182 sobre las Peores Formas de Trabajo Infantil. ${ }^{21}$

De los ocho convenios fundamentales citados, Brasil no ha ratificado el $87 \mathrm{y}$ Cuba no ha ratificado el 182. Por su parte, México no ha ratificado el 98 ni el 138. Y Estados Unidos, aunque no integra el bloque de países iberoamericanos -pero Puerto Rico sí-, apenas ha ratificado dos convenios fundamentales: el 105 y el 182.22

Respecto al Convenio 138, los países especifican la edad mínima para acceder al empleo, estableciendo 14, 15 o 16 años. Pero República Dominicana autoriza el trabajo de los menores de entre 12 y 14 años en trabajos ligeros. ${ }^{23}$

\footnotetext{
14 от. Convenio No. 29 sobre Trabajo Forzoso, adoptado el 28 de junio de 1930, en http://www.lo.org/dyn/normlex/ es/f?p=normLEXPUB:12100:0::No:12100:P12100_InStRUMENT_ID:312174:No [En línea]. [Citado: 17. Septiembre. 2012].

15 от. Convenio No. 87 sobre la Libertad Sindical y la Protección del Derecho de Sindicación, adoptado el 9 de julio de 1948, disponible en: http://www.ilo.org/dyn/normlex/es/f?p=NORMLEXPUB:12100:0::No:12100:P12100_INSTRUMENT _ID:312232:No [En línea]. [Citado: 17. Septiembre. 2012].

${ }^{16}$ отт. Convenio No. 98 sobre el Derecho de Sindicación y Negociación Colectiva, adoptado el 1 de julio de 1949, disponible en: http://www.lo.org/dyn/normlex/es/f?p=NORMLEXPUB:12100:0::No:12100:P12100_INSTRUMENT_ID:312243:NO [En línea]. [Citado: 17. Septiembre. 2012].

17 от. Convenio No. 100 sobre Igualdad de Remuneración, adoptado el 29 de junio de 1951, disponible en: http:// www.lo.org/dyn/normlex/es/f?p=nORMLEXPUB:12100:0::no:12100:P12100_InSTRUMENT_ID:312245:No [En línea]. [Citado: 17. Septiembre. 2012].

18 оाт. Convenio No. 105 sobre la Abolición del Trabajo Forzoso, adoptado el 25 de junio de 1957, disponible en: http://www.ilo.org/dyn/normlex/es/f?p=NORMLEXPUB:12100:0::No:12100:P12100_INSTRUMENT_ID:312250:No [En línea]. [Citado: 17. Septiembre. 2012].

${ }_{19}$ отт. Convenio No. 111 sobre la Discriminación en el Empleo y la Ocupación, adoptado el 25 de junio de 1958, disponible en: http://www.ilo.org/dyn/normlex/es/f?p=1000:12100:0::No::P12100_ILO_CODE:C111 [En línea]. [Citado: 17. Septiembre. 2012].

20 от. Convenio No. 138 sobre Edad Mínima, adoptado el 26 de junio de 1973, disponible en: http://www.ilo.org/dyn/ normlex/es/f?p=nORMLEXPUB:12100:0::No:12100:P12100_INSTRUMENT_ID:312283:No [En línea]. [Citado: 17. Septiembre. 2012].

${ }^{21}$ огт. Convenio 182 sobre Abolición de las Peores Formas de Trabajo Infantil, adoptado el 17 de junio de 1999, disponible en: http://www.llo.org/dyn/normlex/es/f?p=NORMLEXPUB:12100:0::No:12100:P12100_INSTRUMENT_ID:312327:NO [En línea]. [Citado: 17. Septiembre. 2012].

${ }^{22}$ Véase http://www.ilo.org/dyn/normlex/es/f?p=1000:11200:0::No:11200:P11200_counTRY_ID:102871 [En línea]. [Citado: 17. Septiembre. 2012].

${ }^{23}$ Argentina, edad mínima especificada: 16 años. Bolivia, edad mínima especificada: 14 años. Brasil, edad mínima especificada: 16 años. Colombia, edad mínima especificada: 15 años. Costa Rica, edad especificada: 15 años. Chile, edad mínima especificada: 15 años. Cuba, edad mínima especificada: 15 años. Ecuador, edad mínima especificada: 14 años. El Salvador, edad mínima especificada: 14 años. Guatemala, edad mínima especificada: 14 años. Honduras,
} 
En relación con la totalidad de convenios de la oiт (fundamentales, prioritarios o de gobernanza y técnicos), los países que más han ratificado son Uruguay, con 107, y México, con 78. El que menos ha ratificado es Estados Unidos (apenas catorce convenios), seguido por Honduras (veinticinco convenios). ${ }^{24}$

Ahora bien, ¿por qué es necesario referirse a la oıт? Porque los TLCS, al consagrar en su articulado o en instrumentos complementarios la protección y respeto por los derechos de los trabajadores, parten de la oІт para establecer el alcance de la normatividad del trabajo en los países signatarios, en el marco de los tratados celebrados, refiriéndose a los compromisos adquiridos por su carácter de miembros de la огт y en razón de la Declaración sobre Principios y Derechos Fundamentales de 1998; de allí la importancia indiscutible que tienen la огт y, concretamente, esta Declaración.

\section{Principios y derechos fundamentales de los trabajadores en Colombia}

Conforme a JARAmILLO JASSIR, los principios jurídicos se definen como "aquella parte del ordenamiento que tiene por objeto concretar los valores propios de una disciplina determinada en normas orientadoras que constituyen la base de la estructura normativa", y tienen como característica esencial la "inmutabilidad", dada su vocación orientadora, y por ello de forma general se mantienen en el tiempo pese a los cambios normativos. ${ }^{25}$

Guerrero Figueroa define los principios fundamentales del derecho del trabajo como los "postulados que inspiran y definen el sentido de las normas laborales con criterio diferente del de las otras disciplinas jurídicas”. ${ }^{26}$ Según el autor, en

edad mínima especificada: 14 años. Nicaragua, edad mínima especificada: 14 años. República Dominicana, edad mínima especificada: 14 años. Se limita el campo de aplicación del Convenio a las industrias o actividades económicas enumeradas en el artículo 5, párrafo 3, del Convenio. Se permite el empleo de personas de 12 a 14 años de edad en trabajos ligeros, en las condiciones establecidas en el artículo 7, párrafo 4, del Convenio. Panamá, edad mínima especificada: 14 años. Edad mínima para el trabajo marítimo y la pesca marítima y para los menores que no hayan completado la educación básica general: 15 años. Edad mínima para los trabajos subterráneos en las minas: 18 años. Se limita la aplicación del Convenio a las ramas de actividad económica y tipos de empresa enumerados en el artículo 5, párrafo 3. Paraguay, edad mínima especificada: 14 años. Perú, edad minima especificada: 14 años. Uruguay, edad mínima especificada: 15 años. Venezuela, edad mínima especificada: 14 años. Véase http://www.ilo.org/dyn/normlex/ es/f?p=1000:11003:0::No::: [En línea]. [Citado: 17. Septiembre. 2012].

${ }^{24}$ Argentina 76, Bolivia 48, Brasil 96, Chile 61, Colombia 60, Costa Rica 50, Cuba 89, Ecuador 60, República Dominicana 36, El Salvador 30, Guatemala 73, Honduras 25, México 78, Nicaragua 60, Panamá 76, Paraguay 38, Perú 74, Uruguay 107, Venezuela 54, y Estados Unidos 14. Véase http://www.ilo.org/dyn/normlex/es/f?p=1000:12001:0::No::: [En linea]. [Citado: 17. Septiembre. 2012].

25 Jaramillo Jassir, Iván Daniel. Principios constitucionales y legales del derecho del trabajo colombiano, Universidad del Rosario, Bogotá, 2011, colección Textos Jurídicos, p. 15.

${ }^{26}$ Guerrero Figueroa, Guillermo. Principios fundamentales del derecho del trabajo, Leyer, Bogotá, 1999, p. 31. 
Colombia pueden clasificarse en los establecidos en la Constitución con el valor de inspirar la legislación, y los eminentemente jurídicos, que son los reconocidos expresa o tácitamente en los distintos textos que regulan el derecho del trabajo. Hace hincapié en los principios de carácter general, como el derecho del trabajo, dignidad del trabajo, protección al trabajo, libertad de trabajo, mínimos derechos fundamentales referidos en el artículo 53 de la Constitución Política de Colombia, y los de carácter colectivo, como el derecho de asociación sindical, negociación colectiva y huelga. ${ }^{27}$

LóPEZ FAJARDO recuerda que para los autores especializados, los principios fundamentales cumplen una triple misión: informadora (inspiran al legislador o al intérprete), normativa (actúan como fuente supletoria) e interpretadora (operan como criterio orientador). ${ }^{28}$

Por su parte, Juan Manuel ChARRIA menciona que "a partir de la Constitución Política [de 1991]... se hace de la aplicación de los principios la columna vertebral del derecho laboral como derecho vivo, bajo una interpretación realista del derecho positivo". ${ }^{29}$

De todo lo expresado se desgaja que el concepto de principios y derechos establecidos por la oाт como fundamentales, no es el mismo que contempla nuestro ordenamiento jurídico laboral. Y no lo es porque mientras la oıт establece los cuatro básicos para cualquier tipo de relación de trabajo, sin los cuales no puede existir trabajo decente y que constituyen "las bases mínimas para que el progreso social acompañe el progreso económico y el desarrollo", los otros configuran una especie de "complemento" de esos cardinales o esenciales, requiriéndolos para su existencia.

Ahora bien, ¿qué principios y derechos fundamentales en general se consagran en la Constitución colombiana?

El título 1 de la Constitución Política se denomina "derechos fundamentales", mencionando en el primer artículo que el país es un Estado social de derecho fundado en el respeto por la dignidad humana, el trabajo y la solidaridad de sus miembros; y en el segundo, que entre sus fines esenciales está garantizar la efectividad de los principios, derechos y deberes consagrados en la misma. ${ }^{30}$

El capítulo I "De los derechos fundamentales" del título 11 sobre "Derechos, garantías y deberes", contempla en el artículo 12 la prohibición de tratos inhumanos o degradantes, y en el 17 la prohibición de la esclavitud, la servidumbre

\footnotetext{
27 Idem.

${ }^{28}$ Véase López Fajardo, Alberto. Elementos de derecho del trabajo, Librería Ediciones del Profesional Ltda., Bogotá, 2010, p. 91.

${ }^{29}$ Charria Segura, Juan Manuel. Reflexiones constitucionales ॥, Editorial Ibañez, Bogotá, 2012, p. 180.

${ }^{30}$ Constitución Política de Colombia, artículos 1 y 2.
} 
y la trata de seres humanos "en todas sus formas". En el artículo 13 se dispone la igualdad ante la ley. El artículo 20 contiene la garantía a toda persona a la libertad de expresar y difundir su pensamiento y opiniones. El 25 consagra que el trabajo es un derecho y una obligación social y que toda persona tiene derecho a un trabajo en condiciones dignas y justas. El artículo 37 reconoce el derecho de reunión, el 38 el de libre asociación y el 39 el derecho tanto de trabajadores como de empleadores de formar organizaciones sindicales.

Luego, en el capítulo ॥ "De los derechos económicos, sociales y culturales" del mismo título 1, el artículo 43 establece la igualdad de derechos y oportunidades de hombres y mujeres y la prohibición de la discriminación de la mujer. El artículo 53, sobre principios mínimos fundamentales, relaciona entre otros la igualdad de oportunidades para los trabajadores; añade que los convenios internacionales de trabajo debidamente ratificados hacen parte de la legislación interna, y que la ley, los contratos, los acuerdos y convenios de trabajo no pueden quebrantar la libertad, la dignidad humana ni los derechos de los trabajadores. El 55 se refiere a la garantía del derecho de negociación colectiva y al deber estatal de promover la concertación y demás medios para solucionar pacíficamente los conflictos colectivos de trabajo. Y el artículo 56 se refiere al derecho de huelga (salvo en los servicios públicos esenciales).

Los preceptos anteriores configuran el articulado del marco constitucional de los principios y derechos fundamentales en el trabajo, sobre el cual se edifica cada uno de ellos en el Código Sustantivo del Trabajo, en normas complementarias y en pronunciamientos de las altas cortes. Y deberían también erigirse en normas que contemplan relaciones de trabajo independientes.

Colombia ha ratificado los ocho convenios fundamentales de la oit sobre los cuales se construyen los cuatro principios y derechos fundamentales en el trabajo.

\section{A) Libertad de asociación, libertad sindical y reconocimiento efectivo del derecho de negociación colectiva}

Entre los muchos significados que tiene la palabra "libertad" está el más simple: ausencia de restricciones, limitaciones o condiciones; pero como no es absoluta, dichas ausencias no pueden ser arbitrarias. Estas libertades tienen, entre otros sustentos, la libertad de expresión.

La Corte Constitucional colombiana ha definido la libertad de expresión en sentido estricto como: 
El derecho de las personas a expresar y difundir libremente el propio pensamiento, opiniones, informaciones e ideas, sin limitación, a través del medio y la forma escogidos por quien se expresa, la cual puede ser entendida como una libertad negativa pues implica el derecho de su titular a no ser molestado por expresar su pensamiento, opiniones, informaciones o ideas personales, y cuenta con una dimensión individual y una colectiva, pero también como una libertad positiva pues implica una capacidad de actuar por parte del titular del derecho y un ejercicio de autodeterminación. ${ }^{31}$

La misma corporación, en pronunciamiento de 2004, estima que la libertad de expresión tiene límites como la libertad, la finalidad, la necesidad, la veracidad y la integridad. ${ }^{32}$

En tratándose del ámbito del trabajo en Colombia, Aura Carolina LozAno y Melissa PÉrez señalan que:

De la normativa colombiana en materia laboral, se desprende el reconocimiento de la libertad de expresión dentro de las relaciones laborales en el marco de la finalidad del Código Sustantivo del Trabajo expresada en el artículo 1, que es la de lograr la justicia en las relaciones que surgen entre empleadores y trabajadores, dentro de un espíritu de coordinación económica y equilibrio social. ${ }^{33}$

Y expresan también que,

[...] gracias a que dicho derecho se encuentra estipulado y amparado por la Constitución, goza de un especial favor que a su vez implica que sea de obligatorio cumplimiento, sin que pase a ser un derecho de carácter absoluto puesto que admite ciertas limitantes, las que a su vez no pueden constituir una vulneración de otro tipo de derechos de igual o superior rango constitucional. ${ }^{34}$

Conforme a la Corte Constitucional, la libertad sindical

[...] es un concepto bivalente, ya que de una parte es un derecho individual que comporta la facultad de trabajadores y empleadores para constituir los organismos que estimen convenientes, afiliarse o desafiliarse y solicitar su disolución cuando lo estimen pertinente; y de otra, constituye un derecho de carácter colectivo, pues una

\footnotetext{
${ }^{31}$ Corte Constitucional, sentencia c-442 del 25 de mayo de 2011, M.P. Humberto Antonio Sierra Porto.

32 Corte Constitucional, sentencia T-787 del 18 de agosto de 2004, M.P. Rodrigo Escobar Gil.

33 Lozano Ortiz, Aura Carolina y Pérez Zopoaragón, Melissa. "Libertad de expresión en el derecho laboral colombiano", Reflexiones sobre la libertad de expresión en el contexto de la democracia, Fundación Hanns Seidel-Universidad del Rosario, Bogotá, 2012, colección Textos de Jurisprudencia, p. 59.

34 Ibidem, p. 63.
} 
vez constituida la organización, ésta tiene derecho a regir su destino independientemente. ${ }^{35}$

La Corte también ha expresado que "el derecho de asociación sindical representa una garantía de rango constitucional, inherente al ejercicio del derecho al trabajo, y articulado como un derecho con dimensiones tanto individuales como colectivas que representa una vía para la realización del individuo dentro de un Estado social y democrático como el definido por la carta política". Y sobre sus particularidades, establece las siguientes:

a) Voluntario, dado que su ejercicio depende en todo momento de la autodeterminación del individuo para vincularse, permanecer o retirarse de un sindicato.

b) Relacional, pues "de un lado aparece como un derecho subjetivo de carácter individual y por el otro se ejerce necesariamente en tanto haya otros ciudadanos que estén dispuestos a ejercitar el mismo derecho, y una vez se dé el acuerdo de voluntades se forma una persona colectiva".

c) Instrumental, en la medida en que "se crea sobre la base de un vínculo jurídico, necesario para la consecución de unos fines que las personas van a desarrollar en el ámbito de la formación social”. ${ }^{6}$

Aprecia que "ante ese derecho de asociación subyace la idea básica de la libertad sindical" (resaltado en el texto), que amplifica esas prerrogativas "como facultad autónoma para crear organizaciones sindicales, ajena a toda restricción, intromisión o intervención del Estado que signifique la imposición de obstáculos en su constitución o funcionamiento [...]". ${ }^{37}$

Y recuerda otra sentencia de 2000 en la que se presentan los atributos de la libertad sindical: ${ }^{38}$

i) El derecho de todos los trabajadores, sin discriminación ni distinción alguna, para agruparse a través de la constitución de organizaciones permanentes que los identifican como grupos con intereses comunes, y cuya defensa propugnan. Este derecho implica la libertad tanto para afiliarse como para retirarse de dichas organizaciones;

\footnotetext{
${ }^{35}$ Corte Constitucional, Sala Sexta de Revisión, sentencia T-251 del 16 de abril de 2010, M.P. Nilson Pinilla Pinilla.

${ }^{36}$ Corte Constitucional, Sala Cuarta de Revisión, sentencia t-965 del 16 de diciembre de 2011, M.P. Gabriel Eduardo Mendoza Martelo.

${ }^{37}$ Corte Constitucional, sentencia c-385 del 5 de abril de 2000, M.P. Antonio Barrera Carbonell, en Corte Constitucional, Sala Sexta de Revisión, sentencia T-251 del 16 de abril de 2010, M.P. Nilson Pinilla Pinilla.

${ }^{38}$ Corte Constitucional, sentencia c-797 del 29 de junio de 2000, M.P. Antonio Barrera Carbonell.
} 
ii) La facultad de constituir y organizar estructural y funcionalmente las referidas organizaciones y conformarlas automáticamente como personas jurídicas, sin la injerencia, intervención o restricción del Estado;

iii) El poder de las organizaciones de trabajadores de determinar: el objeto de la organización, condiciones de admisión, permanencia, retiro o exclusión de sus miembros, régimen disciplinario interno, órganos de gobierno y representación, constitución y manejo del patrimonio, causales de disolución y liquidación, procedimiento liquidatorio, y otros aspectos que atañen con su estructura, organización y funcionamiento, que deben ser, en principio, libremente convenidos por los miembros de las asociaciones sindicales al darse sus propios estatutos o reformarlos, salvo las limitaciones que válidamente pueda imponer el legislador conforme al inciso $2^{\circ}$ del artículo 39;

iv) La facultad de las asociaciones sindicales para formular las reglas relativas a la organización de su administración, así como las políticas, planes y programas de acción que mejor convengan a sus intereses, con la señalada limitación;

v) La garantía de que las organizaciones de trabajadores no están sujetas a que la cancelación o la suspensión de la personería jurídica sea ordenada por la autoridad administrativa, sino por vía judicial;

vi) El derecho de las organizaciones sindicales para constituir y afiliarse a federaciones y confederaciones nacionales e internacionales;

vii) La inhibición, para las autoridades públicas, incluyendo al legislador, de adoptar regulaciones, decisiones o adelantar acciones que tiendan a obstaculizar el disfrute del derecho a la libertad sindical.

El sustento constitucional del derecho fundamental de asociación sindical y negociación colectiva se halla en los artículos 39 de la Constitución Política (los trabajadores y empleadores tienen derecho a constituir sindicatos o asociaciones, sin intervención del Estado), en el 55 (se garantiza el derecho de negociación colectiva para regular las relaciones laborales, con las excepciones que señale la ley) y en el 56 (se garantiza el derecho de huelga).

En el Código Sustantivo del Trabajo son varias las normas referidas a la libertad sindical y al derecho de asociación sindical (rigen, entre otros, el artículo 353 modificado por el artículo 1 de la Ley 584 de 2000 sobre Derecho de Asociación; el artículo 354 subrogado por el artículo 39 de la Ley 50 de 1990 sobre Protección al Derecho de Asociación, y el artículo 432 sobre delegados en la etapa de arreglo directo). Pero vale la pena aclarar que gran porción de la parte colectiva ha sido derogada o declarada inconstitucional por la Corte Constitucional, lo que quiere decir que el estudio de estos temas se debe hacer a la luz de los convenios y recomendaciones de la olT, de los demás instrumentos internacionales y de los pronunciamientos de la Corte Constitucional. 
De otro lado, la Corte Constitucional ha precisado que el derecho de negociación colectiva no se limita a la presentación de los pliegos de peticiones y a las convenciones colectivas, sino que incluye todas las formas de negociación que se den entre trabajadores y empleadores y que tengan el objetivo de "regular las condiciones del trabajo mediante la concertación voluntaria, la defensa de los intereses comunes entre las partes involucradas en el conflicto económico laboral, la garantía de que los representantes de unos y otros sean oídos y atendidos, así como la consolidación de la justicia social en las relaciones que se den entre los empleadores y los trabajadores". 39

La Corte observa "relaciones apretadas" entre los derechos de asociación sindical y negociación colectiva; este último es consustancial al primero. El de asociación asegura la libertad sindical y es fundamental; sin embargo, el de negociación es un "mecanismo para regular las relaciones laborales y no tiene en principio la connotación de fundamental, la que adquiere cuando su transgresión implica inminencia de vulneración del derecho al trabajo o del derecho de asociación sindical”. ${ }^{40}$

\section{B) Eliminación de todas las formas de trabajo forzoso u obligatorio}

Su sustento constitucional está en los artículos 12 (nadie será sometido a tratos o penas crueles, inhumanos o degradantes; se prohíben la esclavitud, la servidumbre y la trata de seres humanos en todas sus formas) y 25 (toda persona tiene derecho a un trabajo en condiciones dignas y justas).

El principio está relacionado íntimamente con la dignidad de la persona humana, que no es un derecho que tenemos por el hecho de ser personas, sino el "fundamento de las prerrogativas y derechos que como seres humanos tenemos por el simple hecho de existir". ${ }^{41}$

La Corte Constitucional identificó tres lineamientos de la dignidad humana, desde el punto de vista de su protección:

(i) La dignidad humana entendida como autonomía o como posibilidad de diseñar un plan vital y de determinarse según sus características (vivir como quiera). (ii) La

\footnotetext{
${ }^{39}$ Corte Constitucional, sentencia c-280 del 18 de abril de 2007, M.P. Humberto Antonio Sierra Porto; sentencia c-1234 del 29 de noviembre de 2005, M.P. Alfredo Beltrán Sierra, y sentencia c-161 del 23 de febrero de 2000, M.P. Alejandro Martínez Caballero.

${ }^{40}$ Corte Constitucional, sentencia t-251 del 16 de abril de 2010, m.P. Nilson Pinilla Pinilla.

${ }^{41}$ Mendizábal Bermúdez, Gabriela y Jiménez López, Manuel. "Análisis de la dignidad del trabajador en el contexto de la globalización. El ejemplo de México", en Revista Chilena de Derecho del Trabajo y de la Seguridad Social, vol. 3, No. 6, segundo semestre de 2012, p. 167.
} 
dignidad humana entendida como ciertas condiciones materiales concretas de existencia (vivir bien). Y (iii) la dignidad humana entendida como intangibilidad de los bienes no patrimoniales, integridad física e integridad moral (vivir sin humillaciones).

Desde la perspectiva de su funcionalidad normativa, en la misma sentencia se observaron tres lineamientos: "(i) la dignidad humana entendida como principio fundante del ordenamiento jurídico y por tanto del Estado, y en este sentido la dignidad como valor. (ii) La dignidad humana entendida como principio constitucional. Y (iii) la dignidad humana entendida como derecho fundamental autónomo". ${ }^{42}$

En cuanto al trabajo obligatorio en cárceles, aunque no comparte la característica de voluntariedad, ya que el recluso lo realiza para rebajar su condena, la Corte Constitucional, en la sentencia T-429 de 2010, trae a colación el Convenio 29 de la oाт que señala que el trabajo forzoso y obligatorio que debe abolirse no integra "cualquier trabajo o servicio que se exija a un individuo en virtud de una condena pronunciada por sentencia judicial, a condición de que este trabajo o servicio se realice bajo la vigilancia y control de las autoridades públicas y que dicho individuo no sea cedido o puesto a disposición de particulares, compañías o personas jurídicas de carácter privado" ${ }^{43}$

La Corte Constitucional, en la sentencia T-1072 de 2012, ${ }^{44}$ tuteló el derecho de una persona (a quien se identifica como "Amalia") que desde los 6 o 7 años de edad fue esclavizada por parte de una familia en la que fue maltratada y abusada sexualmente. Consideró que a pesar de que los hechos se presentaron muchos años atrás (1963), como se trata de derechos fundamentales gravemente violados (libertad, integridad y dignidad) puede conocer del caso y ordena al Minis-

\footnotetext{
${ }^{42}$ Corte Constitucional, Sala Séptima de Revisión, sentencia T-881 del 17 de octubre de 2002, M.P. Eduardo Montealegre Lynett.

${ }^{43}$ Corte Constitucional, Sala Tercera de Revisión, sentencia T-429 del 28 de mayo de 2010, M.P. Juan Carlos Henao Pérez.

${ }^{44}$ Corte Constitucional, Sala Séptima de Revisión, sentencia T-1078 del 12 de diciembre de 2012, M.P. Jorge Ignacio Pretelt Chaljub.

(Para proteger el derecho a la intimidad, el nombre y el de sus familiares fueron suprimidos con el fin de evitar su identificación; se le denominará "Amalia"). La señora "Amalia" considera que su identidad, familia, justicia, verdad, reparación, libertad, integridad sexual y dignidad humana, como derechos fundamentales, fueron vulnerados por muchísimos años, pues entre julio de 1963 y febrero de 1964, cuando era una niña de escasos 6 o 7 años de edad, el señor xx "se apoderó de ella" y la llevó a Bogotá a la casa de su suegra, donde "Amalia" trabajó como esclava durante 12 años en los cuales fue explotada (tenía extensas jornadas de trabajo sin derecho a una educación; aprendió a leer y escribir "al lado" de los hijos del señor xx; nunca tuvo documento de identificación), maltratada (la metían en la alberca si se orinaba, entre otros castigos) y abusada sexualmente por familiares de la "patrona"; jamás devengó un salario y no se le permitía tener dinero ("era suficiente con darle alimentación, habitación y vestuario" según los demandados). Encontró unos documentos sobre adopción, pero el señor xx nunca le ha querido informar quién es su verdadera familia, aunque en reiteradas ocasiones le dijo que su mamá era prostituta. A comienzos de los años setenta pudo huir de la casa.
} 
terio del Interior brindar asistencia a la accionante para encontrar a su familia y "poder reconstruir su pasado"; y a los demandados, a pagar una indemnización a la tutelante.

\section{c) Abolición efectiva del trabajo infantil}

El artículo 44 de la Constitución Política de Colombia consagra, entre otros derechos fundamentales de los niños, los derechos a la vida, la integridad física, la salud y la seguridad social; los menores serán protegidos contra explotación laboral o económica y contra trabajos riesgosos, y menciona igualmente que los derechos de los niños prevalecen sobre los derechos de los demás. Por su parte, el artículo 53 sobre principios mínimos fundamentales, instaura la protección al trabajador menor de edad.

La ley de infancia y la adolescencia de $2006^{45}$ estableció en el artículo 37 como libertad fundamental de los niños, niñas y adolescentes, la de escoger profesión u oficio. Y señaló en el artículo 114 una jornada especial para los menores de edad, así: los mayores de 15 años y menores de 17 pueden trabajar en jornadas diurnas máximo de 6 horas diarias y 30 a la semana y hasta las 6:00 p.m. Y los adolescentes mayores de 17 años podrán laborar en una jornada máxima de 8 horas diarias y 40 semanales y hasta las 8:00 p.m.

El Comité Interinstitucional para la Erradicación del Trabajo Infantil y la Protección del Joven Trabajador adoptó en 2003 la siguiente definición sobre trabajo infantil: "Es toda actividad física o mental, remunerada o no, dedicada a la producción, comercialización, transformación, venta o distribución de bienes o servicios, realizada en forma independiente o al servicio de otra persona natural o jurídica [...], por personas menores de 18 años de edad". ${ }^{46}$

Pese a ello, no todo trabajo ejecutado por un menor de edad se entiende que es labor que deba excluirse. La oıт estima que "la participación de niños o adolescentes en un trabajo que no afecta su salud y desarrollo personal o interfiera con su educación es considerado por lo general como algo positivo (ayudar en la casa, asistir en un negocio familiar o ganarse dinero para gastos personales fuera de las horas de escuela y durante las vacaciones escolares)". ${ }^{47}$

\footnotetext{
${ }^{45}$ Congreso de la República. Ley 1098 del 8 de noviembre de 2006, "Por la cual se expide el Código de la Infancia y la Adolescencia".

${ }^{46}$ oIT/IPEc. III Plan Nacional para la Erradicación del Trabajo Infantil y Protección del Trabajo Juvenil 2003-2006, Bogotá, Comité Interinstitucional para la Erradicación del Trabajo Infantil y la Protección del Joven Trabajador, 2003, p. 24.

${ }^{47}$ оाт. Trabajo infantil. Un manual para estudiantes, Programa Internacional para la Erradicación del Trabajo Infantil, 2004 , p. 16.
} 
Entonces, ¿en qué consisten las peores formas de trabajo infantil? Son aquellas que atentan contra la dignidad del menor trabajador, siendo nocivas para su desarrollo físico y psicológico. Tiene los siguientes caracteres particulares: "Es física, mental, social o moralmente perjudicial o dañino para el niño, e interfiere en su escolarización privándolos de la oportunidad de ir a la escuela, obligándoles a abandonar prematuramente las aulas, o exigiendo que intenten combinar la asistencia a la escuela con largas jornadas de trabajo pesado". 48

De acuerdo con el Departamento Administrativo Nacional de Estadística (DANE) la tasa de trabajo infantil en los meses de octubre-diciembre de 2012 en Colombia fue del 9.8\%, lo que significa que estaban trabajando 1,111,000 menores de edad entre 5 y 17 años, que equivale a 354,000 menos que en 2011. Las ramas de actividad que agruparon el mayor número de niños, niñas o adolescentes trabajadores fueron la agricultura, pesca, ganadería, caza y silvicultura $(36,6 \%)$, comercio, hoteles y restaurantes (30,4\%). ${ }^{49}$

"La realidad mundial es la existencia del trabajo infantil, pero la tendencia es el esfuerzo de la mayoría de los países para su erradicación total, o por lo menos en sus peores formas". ${ }^{50}$ Aunque en Colombia, tanto el Estado como los gremios tienen como meta suprimirlo del todo para que los menores de edad puedan dedicarse a estudiar de forma completa y así hacer una sociedad más justa y equitativa.

\section{D) Eliminación de la discriminación en materia de empleo y ocupación}

El artículo 13 de la Constitución Política estipula la igualdad ante la ley y la no discriminación por razones de sexo, raza, origen nacional o familiar, lengua, religión, opinión política o filosófica. Y el artículo 43 consagra la igualdad de derechos y oportunidades entre la mujer y el hombre, agregando que la mujer no podrá ser sometida a ninguna clase de discriminación.

Con sustento en la Constitución anterior y también en la vigente, de tiempo atrás en Colombia se han proferido normas sobre eliminación de la discriminación.

En 1990 se desarrolló la Ley que aprobó la Convención sobre la Eliminación de Todas las Formas de Discriminación contra la Mujer, a través del Decreto 1398 de $1990 . .^{1}$

\footnotetext{
48 ldem.

49 DANE. Boletín de prensa, del 22 de abril de 2013, disponible en: http://www.dane.gov.co/files/investigaciones/ boletines/ech/jobinfantil/bol_trabinf_2012x.pdf [En línea]. [Citado: 27. Abril. 2013].

${ }^{50}$ Gómez Hoyos, Diana Maria. "Regulación del trabajo infantil en Colombia y avances en la supresión de sus peores formas", Realidades y tendencias del derecho en el siglo xxı. Derecho laboral, Temis, Pontificia Universidad Javeriana, Facultad de Ciencias Jurídicas, Bogotá, 2010, t. II, p. 415.

51 Presidencia de la República-Ministerio de Relaciones Exteriores. Decreto 1398 del 3 de julio de 1990, "Por el cual se
} 
Más adelante se profirió la ley 931 de $2004,{ }^{52}$ que tiene como objeto la protección estatal a los derechos de los ciudadanos de ser tratados en condiciones de igualdad, sin que puedan ser discriminados en razón de su edad para acceder al trabajo. Asimismo, contempla que las convocatorias públicas o privadas para acceder a un empleo no pueden señalar limitantes de edad, sexo, raza, origen nacional o familiar, lengua, religión u opinión política o filosófica.

En 2008 , la Ley $1257^{53}$ se dictó para adoptar "normas que permitan garantizar para todas las mujeres una vida libre de violencia, tanto en el ámbito público como en el privado, el ejercicio de los derechos reconocidos en el ordenamiento jurídico interno e internacional, el acceso a los procedimientos administrativos y judiciales para su protección y atención, y la adopción de las políticas públicas necesarias para su realización”, estableciéndose, entre otros derechos, "no ser sometidas a tortura o a tratos crueles y degradantes", y ordenando la implementación de ciertas medidas en distintos ámbitos, como en el laboral. ${ }^{54}$

La finalidad de la Ley 1496 de $2011^{55}$ es la garantía de la igualdad salarial entre mujeres y hombres, y la eliminación de cualquier forma de discriminación en materia de retribución salarial.

La Ley 1482 de $2011^{56}$ trata sobre la garantía de la protección de los derechos de las personas que son transgredidos a través de actos de racismo o discriminación, para los que se contemplan prisión y multa, así: “Actos de racismo o

desarrolla la Ley 51 de 1981, que aprueba la Convención sobre la Eliminación de Todas las Formas de Discriminación contra la Mujer, adoptada por las Naciones Unidas".

52 Congreso de la República. Ley 931 del 30 de diciembre de 2004, "Por la cual se dictan normas sobre el derecho al trabajo en condiciones de igualdad en razón de la edad".

53 Congreso de la República. Ley 1257 del 4 de diciembre de 2008, "Por la cual se dictan normas de sensibilización, prevención y sanción de formas de violencia y discriminación contra las mujeres, se reforman los códigos Penal, de Procedimiento Penal, la Ley 294 de 1996 y se dictan otras disposiciones".

${ }^{54}$ Artículo 12. Medidas en el ámbito laboral. El Ministerio de la Protección Social [hoy Ministerio de Trabajo], además de las señaladas en otras leyes, tendrá las siguientes funciones: 1. Promoverá el reconocimiento social y económico del trabajo de las mujeres e implementará mecanismos para hacer efectivo el derecho a la igualdad salarial. 2. Desarrollará campañas para erradicar todo acto de discriminación y violencia contra las mujeres en el ámbito laboral. 3. Promoverá el ingreso de las mujeres a espacios productivos no tradicionales para las mujeres. Parágrafo. Las Administradoras de Riesgos Profesionales (ARP), los empleadores y/o contratantes, en lo concerniente a cada uno de ellos, adoptarán procedimientos adecuados y efectivos para: 1. Hacer efectivo el derecho a la igualdad salarial de las mujeres. 2. Tramitar las quejas de acoso sexual y de otras formas de violencia contra la mujer contempladas en esta ley. Estas normas se aplicarán también a las cooperativas de trabajo asociado y a las demás organizaciones que tengan un objeto similar. 3. El Ministerio de la Protección Social [hoy Ministerio de Trabajo] velará por que las administradoras de riesgos profesionales (ARP) [hoy administradoras de riesgos laborales-ARL] y las juntas directivas de las empresas den cumplimiento a lo dispuesto en este parágrafo.

55 Congreso de la Repúblca. Ley 1496 del 29 de diciembre de 2011, "Por medio de la cual se garantiza la igualdad salarial y de retribución laboral entre mujeres y hombres, se establecen mecanismos para erradicar cualquier forma de discriminación y se dictan otras disposiciones".

${ }^{56}$ Congreso de la República. Ley 1482 del 30 de noviembre de 2011, "Por medio de la cual se modifica el Código Penal y se establecen otras disposiciones". 
discriminación. El que arbitrariamente impida, obstruya o restrinja el pleno ejercicio de los derechos de las personas por razón de su raza, nacionalidad, sexo $\mathrm{u}$ orientación sexual, incurrirá en prisión de doce (12) a treinta y seis (36) meses y multa de diez (10) a quince (15) salarios mínimos legales mensuales vigentes". Sobre la discriminación, la Corte Constitucional ha dicho: ${ }^{57}$

[...] Los casos de discriminación pueden tener origen en normas que coloquen en posición diferente a las mujeres de los hombres, así como también en comportamientos que sean contrarios al principio de igualdad y que ignoren la prohibición de discriminación.

[...]

En los casos de discriminación, máxime cuando ésta se basa en alguno de los criterios históricamente utilizados para crear diferenciaciones injustas, se encuentra que una de las partes dentro del proceso tiene una posición de debilidad con respecto a la otra. En efecto, la parte que sufre la discriminación se encuentra dentro de un grupo que recibe una especial protección en virtud a la desventaja histórica que implica su condición.

[...]

Por estas razones se ha entendido que en los casos de discriminación debe darse una inversión de la carga probatoria. En efecto, exigir que la parte discriminada demuestre el ánimo discriminatorio resulta una imposición exorbitante que tendría como resultado una negación de justicia en muchos de estos casos, teniendo especial consideración el que se haga respecto de sujetos que reciben especial protección por parte del ordenamiento constitucional. Por otro lado, la inversión de la carga probatoria no resulta una exigencia excesiva para la contraparte, ya que si su conducta se ajustó a parámetros constitucionales contará con los elementos necesarios para demostrar que histórica, contextual y laboralmente no ha existido comportamiento alguno que involucre distinciones no legítimas al momento de determinar el acceso a oportunidades $[\ldots]$

Lo anterior nos lleva a concluir que, por lo menos "en el papel”, Colombia sí está haciendo esfuerzos para erradicar la discriminación de todo tipo.

\section{Tratados de libre comercio celebrados por Colombia con Canadá, Chile y Estados Unidos}

Según el sistema de información sobre comercio exterior (SICE) de la Organización de Estados Americanos (OEA), los acuerdos o tratados comerciales en lberoaméri-

\footnotetext{
57 Corte Constitucional, sentencia T-247 del 15 de abril de 2010, M.P. Humberto Antonio Sierra Porto.
} 
ca están en ascenso; así se registra en las estadísticas. ${ }^{58}$ Como ya vimos, apenas dieciocho (entre más de setenta) son los que hacen alusión a derechos laborales.

Colombia tiene vigentes seis TLCs: con Canadá, Chile, la Asociación Europea de Libre Comercio (AELC), Estados Unidos, México y el Triángulo del Norte (El Salvador, Guatemala y Honduras). De éstos, en parcamente tres aparecen los derechos de los trabajadores: ${ }^{59}$ entre Colombia y Estados Unidos, el Acuerdo de Promoción Comercial ${ }^{60}$ tiene el capítulo 17 referido exclusivamente al laboral. El país celebró un TLC con Canadá61 (TLCCCO), cuyo capítulo 16 trata sobre asuntos laborales. ${ }^{62} Y$ también lo hizo con Chile, ${ }^{63}$ que su capítulo 17 se refiere al laboral. ${ }^{64}$

El Tratado entre Colombia y Corea, firmado el 21 de febrero de 2013, no está aún en vigor y no hace alusión al derecho del trabajo, como tampoco el Acuerdo Comercial entre Colombia, Perú y la Unión Europea, que fue suscrito en Bruselas (Bélgica) el 26 de junio de 2012 y aprobado por el Parlamento Europeo el 11 de diciembre de 2012.

El TLC con Chile desarrolla los asuntos del trabajo en el capítulo 17. En él se reafirman las obligaciones de ambos países como miembros de la oाт y los compromisos asumidos en razón de la Declaración de 1998 sobre Principios y Derechos Fundamentales y su seguimiento. Pactan desplegar actividades sobre derechos laborales fundamentales y su aplicación efectiva, trabajo decente, relaciones laborales y condiciones de trabajo. Y entienden por legislación laboral, aquellas leyes, regulaciones o disposiciones sobre los derechos internacionalmente reconocidos:

[...] asociación, derecho de organizarse y negociar colectivamente, prohibición del uso de cualquier forma de trabajo forzoso u obligatorio, edad mínima para el empleo de niños, y la prohibición y eliminación de las peores formas de trabajo infantil, eliminación de la discriminación en materia de empleo y ocupación, y condiciones

\footnotetext{
58 Véase OEA, en http://www.sice.oas.org/agreements_s.asp [En linea]. [Citado: 13. Marzo. 2013].

${ }^{59}$ Chile: firmado el 27 de noviembre de 2006 y vigente desde el 8 de mayo de 2009. Canadá: firmado el 21 de noviembre de 2008 y vigente desde el 15 de agosto de 2011. Estados Unidos: firmado el 22 de noviembre de 2006 y vigente desde el 12 de mayo de 2012, disponible en: http://www.sice.oas.org/agreements_s.asp [En línea]. [Citado: 13. Marzo. 2013].

${ }^{60}$ Firmado el 22 de noviembre de 2006 y vigente desde el 12 de mayo de 2012, disponible en: http://www.sice.oas. org/Trade/CoL_USA_TPA_s/Index_s.asp [En línea]. [Citado: 13. Marzo. 2013].

${ }^{61}$ Firmado el 21 de noviembre de 2008 y vigente desde el 15 de agosto de 2011, disponible en: http://www.sice.oas. org/TPD/AnD_CAN/Final_Texts_CAN_col_s/Index_s.asp [En linea]. [Citado: 13. Marzo. 2013].

${ }^{62}$ Véase http://www.sice.oas.org/TPD/AND_CAN/Final_Texts_CAN_COL_s/Chapter16_s.pdf [En línea]. [Citado: 13. Marzo. 2013].

${ }^{63}$ Firmado el 27 de noviembre de 2006 y vigente desde el 8 de mayo de 2009, disponible en: http://www.sice.oas. org/Trade/CHL_CoL_FA/CHL_CoL_ind_s.asp [En línea]. [Citado: 13. Marzo. 2013].

${ }^{64}$ Véase http://www.sice.oas.org/Trade/cHL_CoL_FA/CHL_col_ind_s.asp\#Labor [En línea]. [Citado: 13. Marzo. 2013].
} 
aceptables de trabajo respecto a salarios mínimos, horas de trabajo y seguridad y salud ocupacional.

El capítulo 16 sobre cuestiones laborales del ALC con Canadá se complementa con un Acuerdo de Cooperación Laboral. En dicho capítulo también se confirman las obligaciones como Estados parte de la olт y los compromisos contraídos por la Declaración de 1998; se asevera su respeto continuo a las Constituciones y leyes de cada país. Entre los objetivos está la promoción de sus deberes con los principios y derechos laborales internacionalmente reconocidos. En el Acuerdo de Cooperación Laboral se asegura que tanto Colombia como Canadá, en sus leyes, reglamentos y prácticas, deben establecer y proveer protección a los derechos y principios internacionalmente reconocidos:

[...] libertad de asociación y derecho a la negociación colectiva (incluyendo la protección del derecho a organizarse y del derecho de huelga), eliminación de todas las formas de trabajo forzoso u obligatorio, abolición efectiva del trabajo infantil (incluyendo protección a niños y jóvenes), eliminación de la discriminación respecto al empleo y la ocupación, condiciones aceptables de trabajo con respecto a salario mínimo, horas de trabajo y salud y seguridad ocupacional, y otorgamiento a los trabajadores migrantes de la misma protección legal que a los nacionales, respecto a las condiciones de trabajo.

El APC con Estados Unidos no solamente contiene el capítulo 17 sobre laboral, sino que cuenta con el Anexo 17.5 referente al Mecanismo de Cooperación Laboral y Desarrollo de Capacidades. También se revalidan las obligaciones como integrantes de la oाт y los compromisos surgidos de la Declaración de 1998; cada parte se cerciorará de que esos principios laborales y los derechos laborales internacionalmente reconocidos consagrados en el artículo 17.7 sean, asimismo, reconocidos y protegidos en las respectivas normatividades: derecho de asociación; derecho de organizarse y negociar colectivamente; prohibición del uso de cualquier forma de trabajo forzoso u obligatorio; protecciones laborales para niños y menores, incluyendo una edad mínima para el empleo de niños; la prohibición y eliminación de las peores formas de trabajo infantil, y condiciones aceptables de trabajo respecto a salarios mínimos, horas de trabajo y salud y seguridad ocupacional. Conforme al Anexo 17.5 se deben implementar actividades de cooperación bilaterales o regionales sobre los derechos y principios fundamentales.

Este último Acuerdo ha sido el más controversial de los tres. Fueron muchos años de negociación de su articulado, grandes debates sobre sus verdaderas ven- 
tajas, "imposición" de Estados Unidos de modificaciones a la legislación laboral colombiana, previas a la firma del Tratado, entre otras cuestiones. Hubo visitas oficiales de Estados Unidos a varias regiones del país para conocer de primera mano las condiciones de trabajo, las quejas de los sindicatos y el funcionamiento de las cooperativas de trabajo asociado (стA).

De acuerdo con Valdés SÁncheZ, Estados Unidos hizo requerimientos previos en el ámbito laboral para la firma del TLc: ${ }^{65}$

Dentro de esos condicionamientos se encuentran varios que tocan con los aspectos laborales internos de Colombia, incluyendo el funcionamiento del Ministerio del ramo especialmente en el cumplimiento de sus funciones de inspección y vigilancia, la utilización de la figura de las cooperativas de trabajo asociado, el irrespeto en varios sectores frente a los lineamientos trazados por la Organización Internacional del Trabajo, particularmente en lo que toca con la Declaración de Principios y Derechos Fundamentales en el Trabajo, amén de otros de menor calado como la implementación de mecanismos de atención oportuna de consultas de contenido laboral y el establecimiento de instrumentos de solución de conflictos en forma ágil u oportuna.

Por lo menos el Acuerdo no obliga a Estados Unidos y a Colombia a crear topes específicos de salario mínimo; simplemente el compromiso a acatarlo, cualquiera que sea, como bien lo señala AbuSAID Gómez. ${ }^{66}$

Pero ¿qué ventajas traen los TLcs en el ámbito laboral, cuando simplemente se ratifica en su texto la vinculación de los Estados a la oıт, se recuerdan los compromisos que ese hecho conlleva y aquellos deberes originados de la Declaración de 1998 y el reconocimiento a los principios y derechos fundamentales en el trabajo? Los TLCS, como acuerdos que son para ensanchar y optimizar el mercado de servicios y bienes, debieron contener estipulaciones sociales o laborales desde un principio, pero no fue asi; aunque algunos estiman que no es necesaria tal inclusión, por cuanto la mayoría de países del hemisferio (185) forman parte de la огт, y con ello es suficiente. Empero, es de recibo que en países subdesarrollados como Colombia, la inserción de cláusulas laborales en TLCs no es una mera repetición de enunciados básicos de trabajo; es una forma de hacer cumplir los mínimos derechos y garantías establecidos en la normatividad vigente, que en comprobados casos no se da.

\footnotetext{
${ }^{65}$ Valdés Sánchez, Germán Gonzalo. "Implicaciones de los tratados de libre comercio en el derecho del trabajo. Retos de la competitividad nacional. Pros y contras de las recientes reformas laborales con ocasión del TLC", ponencia presentada en el xxx Congreso Nacional de Derecho del Trabajo y de la Seguridad Social de Colombia, abril de 2012, p. 3.

${ }^{66}$ Abusaid Gómez, José Alejandro. Negocios exitosos. tlc Colombia-Estados Unidos, implementación y análisis, Legis, Bogotá, 2013, p. 265.
} 
Bien lo expresa Raúl SACo BarRIOS, citado por Katherine BERMÚDEZ: ${ }^{67}$

La vinculación de asuntos laborales al comercio trae como ventajas que se fomenta la competencia leal, se fijan unos estándares mínimos laborales a nivel internacional con los que se protege a los trabajadores de ser explotados y se ayuda a mejorar las condiciones de trabajo de quienes están vinculados a los sectores exportadores, en cuanto sus empleadores saben que pueden hacer responsables a sus Estados de eventuales sanciones económicas si no respetan los derechos laborales de sus trabajadores.

\section{Tratados de libre comercio en otros países de lberoamérica, y su comparación en asuntos laborales con los suscritos por Colombia}

Varios de los demás países de lberoamérica han celebrados TLcs con alusión a derechos laborales, así:

El Acuerdo de Cooperación Laboral entre Chile y Canadá, ${ }^{68}$ que hace parte del TLC entre los mismos países, formula entre sus objetivos "promover al máximo los principios laborales establecidos en el Anexo 1". Consta de un Acuerdo de Cooperación Laboral y de anexos. Legislación laboral, igual que en el TLC entre Colombia y Estados Unidos, significa leyes, reglamentos o disposiciones que están relacionados con la libertad de asociación y protección del derecho de organización, derecho a la negociación colectiva, derecho de huelga, prohibición del trabajo forzado, protección en el trabajo para los niños y los menores, condiciones mínimas de trabajo (tales como el pago de salarios mínimos y de horas extra), pero agrega igual remuneración para hombres y mujeres y la eliminación de la discriminación laboral por motivos raciales, religiosos, de edad, sexo u otras razones, según establezcan las leyes internas de cada parte. En las condiciones mínimas de trabajo integra a los "asalariados e incluye a los que no están cubiertos por contratos colectivos". Este Tratado no menciona a los trabajadores migrantes, como sí lo hace el ALc entre Colombia y Canadá.

En el Anexo 1 sobre principios laborales se esbozan lineamientos para delimitar las normas que protegen los derechos laborales, como son libertad de asociación sindical, derecho a la negociación colectiva, derecho de huelga, prohibición

\footnotetext{
${ }_{67}$ SAco BarRIos, Raúl. "Cláusulas sociales en los tratados internacionales de comercio", v Congreso Regional Americano de Derecho del Trabajo y de la Seguridad Social, Sociedad Peruana de Derecho del Trabajo y de la Seguridad Social, Lima, 2001, p. 328. Citado por Bermúdez, Katherine. "tlc Estados Unidos: ¿qué implica en lo laboral?", en Revista Actualidad Laboral y Seguridad Social, No. 169, enero-febrero de 2012, p. 11.

${ }^{68}$ Firmado el 5 de diciembre de 1996 y en vigencia desde el 5 de julio de 1997, en http://www.sice.oas.org/Trade/ chican_s/Labor.asp\#\#ream [En línea]. [Citado: 7. Enero. 2013].
} 
de trabajo forzoso, protección en el trabajo para "niños y menores", condiciones laborales mínimas (salario mínimo y pago de horas extras), eliminación de discriminación laboral e igual remuneración para hombres y mujeres.

El TLC entre Chile y China lo complementa un "Memorándum de entendimiento de cooperación laboral y de seguridad social" entre los ministerios del Trabajo de ambos países. ${ }^{69}$ Acuerdan actividades de cooperación en temas tales como políticas de empleo, trabajo y diálogo social (incluyendo trabajo decente, legislación laboral e inspección del trabajo), mejoramiento de las condiciones laborales y capacitación a los trabajadores, globalización y su impacto en el empleo, el medio ambiente laboral, relaciones laborales y su regulación, y finalmente seguridad social.

El TLC entre Chile y Estados Unidos está conformado por el capítulo 18, relacionado con lo laboral, ${ }^{70}$ y además lo complementa el Anexo 18.5 respecto a mecanismos de cooperación laboral. Tanto el artículo 17.7 del TLC entre Colombia y Estados Unidos como el artículo 18.8 del TLC entre Chile y Estados Unidos sobre "definiciones de legislación laboral" son iguales.

El Acuerdo entre Chile y Japón para una "asociación económica estratégica” contiene una Declaración conjunta, ${ }^{71}$ "convencidos de la necesidad de proteger los derechos laborales"; reafirman sus obligaciones como miembros de la oІт y su compromiso con los principios de la Declaración de 1998.

Aunque en el preámbulo del TLC entre Chile y México se lee: “[...] decididos a crear nuevas oportunidades de empleo, mejorar las condiciones laborales y los niveles de vida de sus respectivos territorios", ${ }^{72}$ no contiene un capítulo referido al laboral ni un instrumento complementario sobre el tema.

Al Acuerdo Estratégico Transpacífico de Asociación Económica, firmado por los gobiernos de Chile, Brunei Darussalam, Nueva Zelandia y Singapur, decididos a "consolidar su alianza económica y estratégica de manera de lograr beneficios económicos y sociales, crear nuevas oportunidades de empleo y mejorar los niveles de vida de sus pueblos", ${ }^{73}$ lo complementa un "Memorándum de entendimiento sobre cooperación laboral" que, entre otros objetivos, contempla el de "promover una mejor comprensión y observancia de los principios incorporados en la Declaración de la ort relativa a los Principios y Derechos Fundamentales

\footnotetext{
${ }^{69}$ Véase http://www.sice.oas.org/Trade/CHL_CHN/CHL_CHn_s/Labor_s.asp [En línea]. [Citado: 13. Marzo. 2013].

${ }^{70}$ Firmado el 6 de junio de 2003 y vigente desde el 1 de enero de 2004, en http://www.sice.oas.org/Trade/chiusa_s/ Text_s.asp\#Chap18s [En línea]. [Citado: 4. Diciembre. 2012].

${ }^{71}$ Véase http://www.sice.oas.org/Trade/CHL_JpN/Decl_2007.pdf [En línea]. [Citado: 13. Marzo. 2013].

72 Véase http://www.sice.oas.org/trade/chmefta/indice.asp [En línea]. [Citado: 10. Noviembre. 2012].

${ }^{73}$ Firmado el 18 de julio de 2005 y vigente desde el 8 de noviembre de 2006 (Chile), 12 de julio de 2006 (Brunei Darussalam), y 28 de mayo de 2006 (Nueva Zelandia y Singapur). Véase http://www.sice.oas.org/Trade/cHL_Asia_s/ TransPacific_ind_s.asp\#mecl [En línea]. [Citado: 6. Febrero. 2013].
} 
en el Trabajo y su seguimiento", propendiendo a la mejora de las condiciones laborales, mejorar y hacer cumplir los derechos básicos de los trabajadores y compartiendo la aspiración de que el libre comercio conduce al trabajo decente.

En el anterior Acuerdo se hace nuevamente indicación de la Declaración de la oit de 1998, como lo hace la mayoría de los TLCs que incluyen temas laborales, bien en su clausulado o en instrumentos anexos.

El ALC entre Chile y Perú74 tiene un "Memorándum de entendimiento sobre cooperación laboral y migratoria" entre los países, comprometiéndose a "promover el desarrollo de políticas y prácticas laborales y migratorias que mejoren las condiciones de trabajo y los niveles de vida en el territorio de las partes”. Se reafirman los compromisos de las partes como integrantes de la olт y en virtud de la Declaración de 1998.

El TLC entre Costa Rica y Canadá (firmado el 23 de abril de 2001 y en vigencia desde el 1 de noviembre de 2002) lo remata un Acuerdo de Cooperación Laboral,${ }^{75}$ en el que se reafirma una vez más la afiliación a la oıт. En la definición sobre "legislación laboral" incluye también la jurisprudencia, lo que no se hace en los TLCS suscritos por Colombia, o en los demás tratados de lberoamérica. Y en cuanto a los principios y derechos, establece la libertad de asociación y protección del derecho a organizarse, el derecho a la negociación colectiva, el derecho de huelga, la prohibición del trabajo forzado, la protección en el trabajo para los niños y los jóvenes, la eliminación de la discriminación, e igual remuneración para mujeres y hombres.

Al TLC de América del Norte (TLCAN), que tiene como países signatarios a México, Canadá y Estados Unidos, ${ }^{76}$ lo complementa un Acuerdo de Cooperación Laboral, con 7 partes, 55 artículos y 7 anexos, que entró también en vigor el 1 de enero de 1994. Consagra como principios laborales el derecho a constituir organizaciones sindicales, el derecho a la negociación colectiva, la protección del derecho de huelga, la prohibición del trabajo forzado, restricción sobre el trabajo de menores, condiciones mínimas de trabajo, eliminación de la discriminación en el empleo y el salario igual para hombres y mujeres.

El TLC entre Nicaragua y la República de China (Taiwán) contiene en su capítulo 18 la mención al laboral en sus anexos 18.01 sobre principios laborales, y 18.05 referido a mecanismos de cooperación laboral y desarrollo de capacidades.

\footnotetext{
74 Firmado el 22 de agosto de 2006 y vigente desde el 1 de marzo de 2009, en http://www.sice.oas.org/Trade/ CHL_PER_FA/Index_s.asp [En línea]. [Citado: 13. Marzo. 2013].

${ }^{75}$ Véase http://www.sice.oas.org/Trade/cancr/spanish/labor1s.asp [En línea]. [Citado: 13. Marzo. 2013].

${ }^{76}$ Firmado el 17 de diciembre de 1992 y en vigencia desde el 1 de enero de 1994, disponible en: http://www.sice.oas. org/Trade/nafta_s/Indice1.asp [En línea]. [Citado: 6. Febrero. 2013].
} 
El capítulo 16 del TPC entre Panamá y Estados Unidos ${ }^{77}$ es sobre los derechos fundamentales laborales que se adoptarán y mantendrán en leyes y reglamentos, y se aplicarán los derechos definidos en la Declaración de la oІт de 1998.

El APC entre Perú y Estados Unidos en su capítulo $17^{78}$ trata sobre los aspectos laborales, incluyendo la eliminación de la discriminación con respecto a empleo y ocupación que no se estableció en el artículo 17.7 del TLC entre Colombia y Estados Unidos. Lo complementa el Anexo 17.6 respecto al mecanismo de cooperación laboral y desarrollo de capacidades.

El TLC entre Perú y Canadá lo compone un Acuerdo de Cooperación Laboral, ${ }^{79}$ que incluye los principios y derechos fundamentales instituidos en la Declaración de la oit de 1998 y además se refiere a las "condiciones aceptables de trabajo con respecto a salarios mínimos, horas de trabajo y seguridad y salud en el trabajo y a proporcionar a los trabajadores migrantes la misma protección legal que a sus nacionales, respecto a las condiciones de trabajo", que surgen del Programa de Trabajo Decente de la оाт.

Respecto al TLC Perú-Corea del Sur, ${ }^{80}$ su corto capítulo 18 se refiere al laboral, señalando los derechos laborales fundamentales y la aplicación y cumplimiento de la legislación laboral. Recuerda que los países hacen parte de la oाт y por tanto deben cumplir sus compromisos adquiridos en razón de la Declaración de Derechos y Principios Fundamentales de 1998.

El TLC entre República Dominicana, Estados Unidos y Centroamérica (Costa Rica, El Salvador, Guatemala, Honduras y Nicaragua) ${ }^{81}$ se refiere en su capítulo 16 al laboral, incluyendo la declaración de compromisos compartidos y la aplicación de la legislación laboral, entre otros. Deben garantizarse los derechos laborales internacionalmente reconocidos.

Finalmente, el Acuerdo de Asociación Económica entre CARIFORUM (que lo integran República Dominicana y 14 países más ${ }^{82}$ y la Comunidad Europea contiene

\footnotetext{
77 Firmado el 28 de junio de 2007 y en vigencia desde el 31 de octubre de 2012, disponible en: http://www.sice.oas. org/Trade/PAN_USA_TPA_Text0607_s/Index_s.asp\#llaboral [En línea]. [Citado: 20. Marzo. 2013].

${ }_{78}$ Firmado el 12 de abril de 2006 y en vigencia desde el 1 de febrero de 2009, disponible en: http://www.sice.oas.org/ Trade/PER_USA/PER_USA_s/Index_s.asp\#disp_laborales [En línea]. [Citado: 20. Marzo. 2013].

79 Véase http://www.sice.oas.org/Trade/CAn_PER/CAN_PER_s/Labour_CPFTA_s.asp [En línea]. [Citado: 7. Enero. 2013].

${ }^{80}$ Firmado el 14 de noviembre de 2010 y en vigencia desde el 1 de agosto de 2011, disponible en: http://www.sice. oas.org/trade/PER_KOR_FA/Texts_26JuL2011_S/PER_KOR_ToC_s.asp [En línea]. [Citado: 7. Enero. 2013].

${ }^{81}$ Firmado el 5 de agosto de 2005 y en vigencia desde el 1 de marzo de 2006 (El Salvador y Estados Unidos), 1 de abril de 2006 (Honduras y Nicaragua), 1 de julio de 2006 (Guatemala), 1 de marzo de 2007 (República Dominicana) y 1 de enero de 2009 (Costa Rica). Disponible en: http://www.sice.oas.org/Trade/CAFAa/CAFtadr/CAFAdrin_S.asp\#Laboral [En línea]. [Citado: 6. Febrero. 2013].

${ }^{82}$ Antigua y Barbuda, Commonwealth de las Bahamas, Barbados, Belice, Commonwealth de Dominica, Granada, República Cooperativa de Guyana, República de Haiti, Jamaica, San Cristóbal y Nieves, Santa Lucía, San Vicente y las Granadinas, República de Surinam, República de Trinidad y Tobago. En http://www.sice.oas.org/Trade/CAR_EU_EPA_S/ CAR_EU_s.asp\#Part1 [En línea]. [Citado: 6. Febrero. 2013].
} 
en su capítulo 5 aspectos sociales, en el que se revalida el compromiso con las "normas fundamentales del trabajo reconocidas a nivel internacional" (como se define en los convenios de la orT), con la integración a la olT y con la Declaración sobre Principios y Derechos Fundamentales de 1998.

Como el lector puede observar, los tratados y acuerdos mencionados que integran aspectos laborales tienen el mismo "hilo conductor", refiriéndose siempre a la olт y a su Declaración sobre Principios y Derechos Fundamentales de 1998.

\section{Conclusiones}

La globalización y la internacionalización han producido mutaciones económicas, laborales, sociales, etcétera, lo que hace que cada vez con mayor asiduidad se den acuerdos o tratados comerciales para mejorar el comercio y permitir el tránsito de personas y de bienes.

Afirma VALdÉs SÁncheZ que "el poder económico es el que fija las condiciones para el desarrollo de todas las actividades en las diferentes comunidades y quien no se ajusta a ellas va quedando más prontamente marginado en todos los ámbitos, incómodo designio que se aplica en todos los niveles, trátese de relaciones personales, regionales, nacionales o internacionales". ${ }^{83}$

Si bien desde los años noventa los países comenzaron a suscribir TLCs, es a partir de este siglo en el que se evidencia su incremento. $Y$ en lo que respecta a aquellos celebrados por países de lberoamérica, entre ellos o con Estados de otras regiones del mundo, son varios (pero no muchos) los que incluyen asuntos laborales; éstos, casi en su totalidad, referidos a los compromisos adquiridos por los países en su calidad de miembros de la oІт y, asimismo, reconociendo la Declaración de 1998 del mismo organismo internacional sobre Principios y Derechos Fundamentales en el Trabajo.

Aunque en un principio en los acuerdos o tratados comerciales no se tenían en cuenta los asuntos laborales, ahora poco a poco los temas del trabajo están llamados a ser parte integrante de los mismos. Según algunos, su inclusión en los TLCS no genera mayores cambios, por cuanto la regla es la evocación a la oाт y a la Declaración de 1998 sobre Principios y Derechos Fundamentales, y simplemente sin dicho señalamiento se sobreentiende que los países miembros de la oit deben acatar su Constitución, sus declaraciones y cumplir con los compromisos adquiridos. Otros consideran que la importancia es tal, que en los países en los que se aplica el Tratado, los derechos laborales que antes habían sido desconocidos y estaban rezagados a un segundo plano, ahora sí se aplican y pueden exigirse.

\footnotetext{
${ }^{83}$ VAldÉs Sánchez. op. cit., p. 1.
} 
Los TLcs hacen que los países que los suscriben se obliguen a cumplir su propia normatividad laboral y a no desmejorar las condiciones de los trabajadores. Sin embargo, por otro lado se estima que un capitulo laboral en un TLC no garantiza la protección de los derechos de los empleados, porque a la fecha ninguno de los países que ha suscrito TLCs que envuelven asuntos laborales ha demandado a otro por incumplimiento cuando se ha verificado que hay desconocimiento de la legislación en materia laboral.

Sí parece ser un hecho que si un país sin TLC posee relaciones comerciales con otro, con el que diversos países ya tienen suscritos TLCS, queda en desventaja competitiva.

Los TLCS que incluyen cuestiones laborales, las tratan de manera muy similar, haciendo mención a la oıт y a la Declaración de Principios y Derechos Fundamentales de 1998. En pocos casos las diferencias hacen relación con la integración de asuntos migratorios y de seguridad social, que en escasos tucs están plasmados.

La conveniencia de la firma de TLCs ha estado siempre en entredicho. A Colombia le beneficia suscribirlos y más aún integrar los asuntos laborales en ellos, por cuanto, al ser un país subdesarrollado -aunque en constante crecimiento-, permitirá de forma directa o indirecta que se evite la transgresión de los derechos y garantías laborales mínimos de los trabajadores. 
Tratados de libre comercio en países iberoamericanos (Con mención al derecho del trabajo), abril de 2013

\begin{tabular}{|c|c|c|c|}
\hline Paises signatarios & 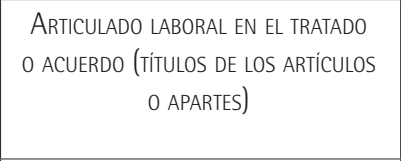 & $\begin{array}{l}\text { ACUERDOS COMPLEMENTARIOS / MEMORÁN- } \\
\text { DUMS / MECANISMOS DE COOPERACIÓN LABO- } \\
\text { RAL / DECLARACIONES CONJUNTAS / ANEXOS } \\
\text { (TítULOS DE LOS ARTICULOS O APARTES) }\end{array}$ & $\begin{array}{c}\text { REFERENCIA A PRINCIPIOS Y DERECHOS FUNDAMENTALES } \\
\text { EN EL TRABAJO Y OTROS TEMAS } \\
\text { (TRANSCRIPCIÓN DE APARTES PERTINENTES) }\end{array}$ \\
\hline 1. Colombia-Estados Unidos & $\begin{array}{l}\text { ACUERDO DE PROMOCIÓN ComerCIAL } \\
\text { Firmado el } 22 \text { de noviembre de } \\
2006 \text { y vigente desde el } 12 \text { de } \\
\text { mayo de } 2012 \text {. } \\
\text { Capitulo 17 (Laboral): } \\
\text { Artículo 17.1: Declaración de } \\
\text { compromisos compartidos. } \\
\text { Artículo 17.2: Aplicación de la } \\
\text { legislación laboral. } \\
\text { Artículo 17.3: Garantías proce- } \\
\text { sales e información pública. } \\
\text { Artículo 17.4: Estructura insti- } \\
\text { tucional. } \\
\text { Artículo 17.5: Mecanismo de } \\
\text { cooperación laboral y desarrollo } \\
\text { de capacidades. } \\
\text { Artículo 17.6: Consultas labora- } \\
\text { les cooperativas. } \\
\text { Artículo 17.7: Definiciones. }\end{array}$ & $\begin{array}{l}\text { ANEXO 17.5. MECANISMO DE COOPERACIÓN } \\
\text { LABORAL Y DESARROLLO DE CAPACIDADES } \\
\text { 1. Coordinación y supervisión. } \\
\text { 2. Prioridades de cooperación y de- } \\
\text { sarrollo de capacidades. } \\
\text { 3. Implementación de actividades de } \\
\text { cooperación. } \\
\text { 4. Participación pública. }\end{array}$ & $\begin{array}{l}\text { AcUeRdo DE PROMoción COMERCIAL } \\
\text { Artículo 17.1.1: Declaración de compromisos } \\
\text { compartidos. } \\
\text { Las Partes reafirman sus obligaciones como } \\
\text { miembros de la Organización Internacional del } \\
\text { Trabajo (oIT) y sus compromisos asumidos en } \\
\text { virtud de la Declaración de la olt relativa a los } \\
\text { Principios y Derechos Fundamentales en el Tra- } \\
\text { bajo y su Seguimiento (1998) (Declaración de } \\
\text { la oIT). Cada Parte procurará asegurar que tales } \\
\text { principios laborales y los derechos laborales in- } \\
\text { ternacionalmente reconocidos establecidos en el } \\
\text { artículo 17.7, sean reconocidos y protegidos por } \\
\text { su legislación. } \\
\text { Artículo 17.2: Aplicación de la legislación laboral. } \\
\text { 1. (a) Una Parte no dejará de aplicar efectiva- } \\
\text { mente su legislación laboral, por medio de un } \\
\text { curso de acción o inacción sostenido o recurren- } \\
\text { te, de una manera que afecte el comercio entre } \\
\text { las Partes, después de la fecha de entrada en vi- } \\
\text { gor de este Acuerdo. } \\
\text { Artículo 17.7: Definiciones. Para los propósitos } \\
\text { de este capítulo: }\end{array}$ \\
\hline
\end{tabular}




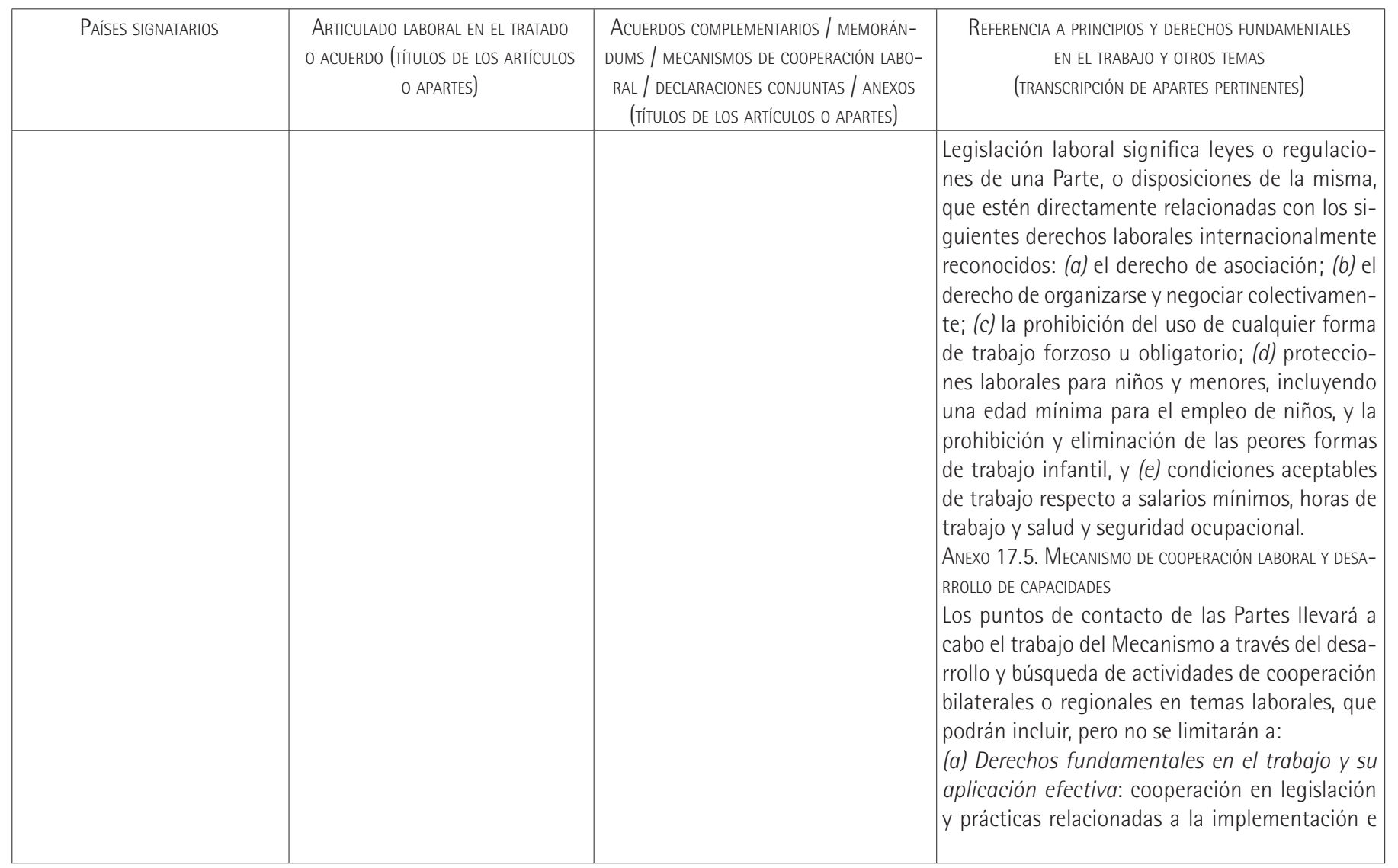




\begin{tabular}{|c|c|c|c|}
\hline Paises SIGNATARIOS & $\begin{array}{l}\text { ARTICULADO LABORAL EN EL TRATADO } \\
\text { O ACUERDO (TitulOS DE LOS ARTICULOS } \\
\text { O APARTES) }\end{array}$ & $\begin{array}{l}\text { ACUERDOS COMPLEMENTARIOS / MEMORÁN- } \\
\text { DUMS / MECANISMOS DE COOPERACIÓN LABO- } \\
\text { RAL / DECLARACIONES CONJUNTAS / ANEXOS } \\
\text { (TítULOS DE LOS ARTICULOS O APARTES) }\end{array}$ & $\begin{array}{c}\text { REFERENCIA A PRINCIPIOS Y DERECHOS FUNDAMENTALES } \\
\text { EN EL TRABAJO Y OTROS TEMAS } \\
\text { (TRANSCRIPCIÓN DE APARTES PERTINENTES) }\end{array}$ \\
\hline & & & $\begin{array}{l}\text { información pública de los principios y derechos } \\
\text { contenidos en la Declaración de la oı: (i) liber- } \\
\text { tad de asociación y reconocimiento efectivo del } \\
\text { derecho de negociación colectiva, (ii) elimina- } \\
\text { ción de todas las formas de trabajo forzoso u } \\
\text { obligatorio, (iii) la abolición efectiva del trabajo } \\
\text { infantil, y (iv) la eliminación de la discriminación } \\
\text { en materia de empleo y ocupación. } \\
\text { (b) Peores formas de trabajo infantil: programas } \\
\text { u otras formas de cooperación para promover el } \\
\text { cumplimiento del Convenio } 182 \text { de la olt sobre la } \\
\text { Prohibición y Acción Inmediata para la Elimina- } \\
\text { ción de las Peores Formas de Trabajo Infantil [...]. }\end{array}$ \\
\hline 2. Colombia-Canadá & $\begin{array}{l}\text { AcueRdo de LIBRE ComerCio (tLCCCO) } \\
\text { Firmado el } 21 \text { de noviembre de } \\
2008 \text { y vigente desde el } 15 \text { de } \\
\text { agosto de } 2011 . \\
\text { Capítulo dieciséis (Asuntos la- } \\
\text { borales): } \\
\text { Articulo 1601: Afirmaciones. } \\
\text { Artículo 1602: No derogación. } \\
\text { Artículo 1603: Objetivos. } \\
\text { Artículo 1604: Obligaciones. } \\
\text { Artículo 1605: Actividades de } \\
\text { cooperación. }\end{array}$ & $\begin{array}{l}\text { AcuERDO DE COOPERACIÓN LABORAL } \\
\text { Preámbulo. } \\
\text { Primera parte. Obligaciones. } \\
\text { Artículo 1: Obligaciones generales. } \\
\text { Articulo 2: No derogación. } \\
\text { Artículo 3: Medidas de aplicación } \\
\text { gubernamental. } \\
\text { Artículo 4: Acceso de los particulares } \\
\text { a los procedimientos. } \\
\text { Artículo 5: Garantías procesales. } \\
\text { Artículo 6: Información y conoci- } \\
\text { mientos públicos. }\end{array}$ & $\begin{array}{l}\text { ACUERDO DE LIBRE COMERCIO } \\
\text { Artículo 1601: Afirmaciones. } \\
\text { Las Partes afirman sus obligaciones como miem- } \\
\text { bros de la Organización Internacional del Trabajo } \\
\text { (oIT) y sus compromisos asumidos en la Declara- } \\
\text { ción de la oIT sobre Principios y Derechos Funda- } \\
\text { mentales del Trabajo (1998) y su Seguimiento, } \\
\text { así como su respeto continuo de las Constitu- } \\
\text { ciones y las leyes de cada una. }\end{array}$ \\
\hline
\end{tabular}




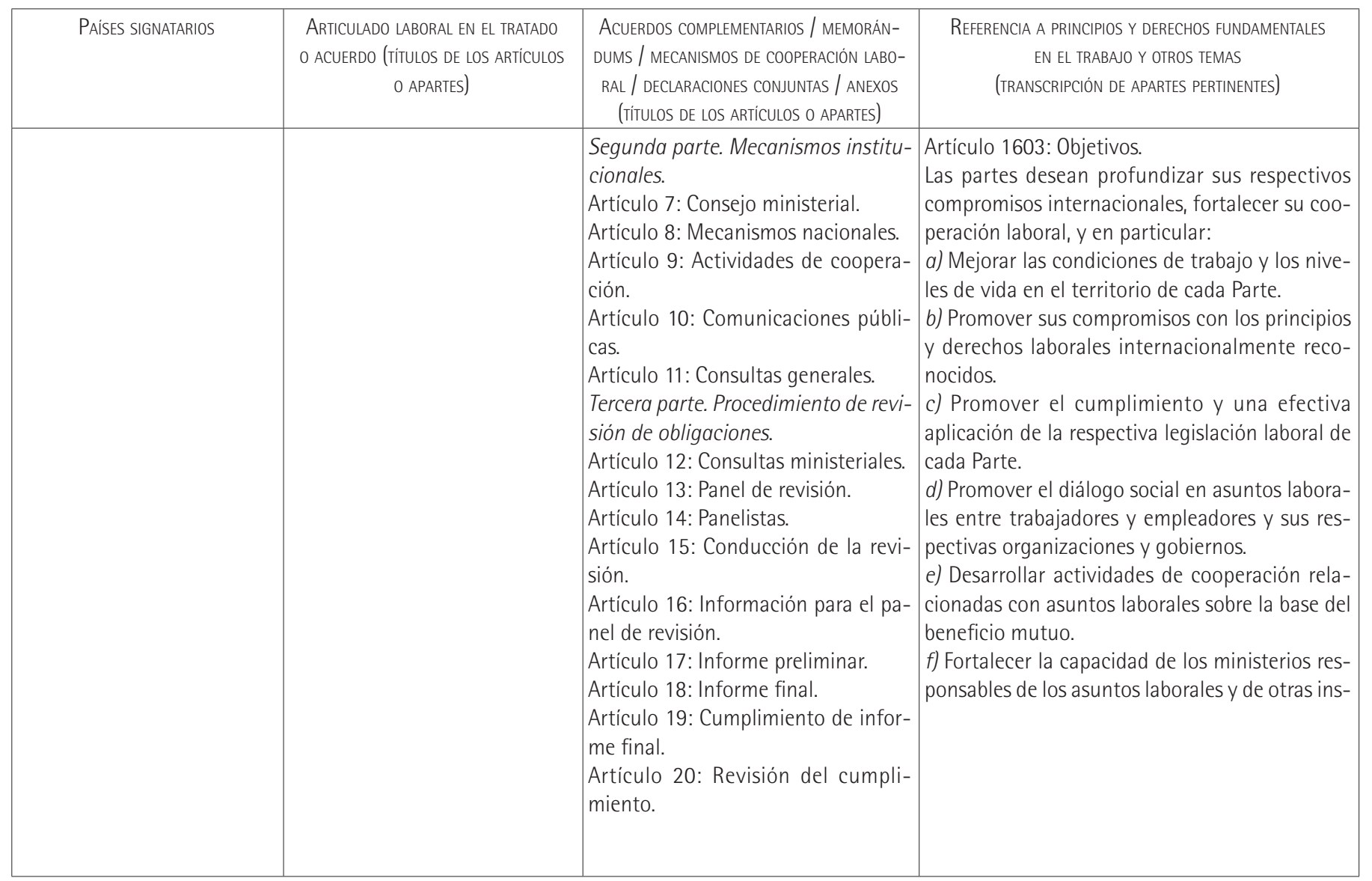




\begin{tabular}{|c|c|c|c|}
\hline PaISES SIGNATARIOS & 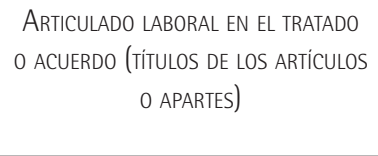 & $\begin{array}{l}\text { ACUERDOS COMPLEMENTARIOS / MEMORÁN- } \\
\text { DUMS / MECANISMOS DE COOPERACIÓN LABO- } \\
\text { RAL / DECLARACIONES CONJUNTAS / ANEXOS } \\
\text { (TitULOS DE LOS ARTICULOS O APARTES) }\end{array}$ & $\begin{array}{c}\text { REFERENCIA A PRINCIPIOS Y DERECHOS FUNDAMENTALES } \\
\text { EN EL TRABAJO Y OTROS TEMAS } \\
\text { (TRANSCRIPCIÓN DE APARTES PERTINENTES) }\end{array}$ \\
\hline & & $\begin{array}{l}\text { Artículo 21: Revisión de conformi- } \\
\text { dad. } \\
\text { Cuarta parte. Disposiciones gene- } \\
\text { rales. } \\
\text { Artículo 22: Principio de aplicación. } \\
\text { Artículo 23: Derechos de particula- } \\
\text { res. } \\
\text { Artículo 24: Protección de informa- } \\
\text { ción. } \\
\text { Artículo 25: Cooperación con orga- } \\
\text { nismos nacionales y regionales. } \\
\text { Artículo 26: Definiciones. } \\
\text { Quinta parte. Disposiciones finales. }\end{array}$ & $\begin{array}{l}\text { tituciones responsables de administrar y aplicar } \\
\text { la legislación laboral en los territorios de cada } \\
\text { Parte, y } \\
\text { g) Fomentar un intercambio abierto y completo } \\
\text { de información entre las Partes en relación con } \\
\text { su legislación laboral, su aplicación y las institu- } \\
\text { ciones en los territorios de cada Parte. } \\
\text { AcuerDo DE CooperAción LABORAL } \\
\text { Primera parte. Obligaciones. } \\
\text { Artículo 1: Obligaciones generales. } \\
\text { 1. Cada Parte asegurará que sus leyes, reglamen- } \\
\text { tos y prácticas correspondientes, contengan y } \\
\text { provean protección a los siguientes derechos y } \\
\text { principios internacionalmente reconocidos: } \\
\text { (a) La libertad de asociación y derecho a la ne- } \\
\text { gociación colectiva (incluyendo la protección del } \\
\text { derecho a organizarse y del derecho de huelga). } \\
\text { (b) La eliminación de todas las formas de trabajo } \\
\text { forzoso u obligatorio. } \\
\text { (c) La abolición efectiva del trabajo infantil (in- } \\
\text { cluyendo protección a niños y jóvenes). } \\
\text { (d) La eliminación de la discriminación respecto } \\
\text { al empleo y la ocupación. }\end{array}$ \\
\hline
\end{tabular}




\begin{tabular}{|c|c|c|c|}
\hline PAISES SIGNATARIOS & 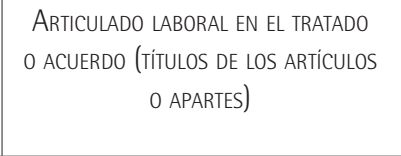 & $\begin{array}{l}\text { ACUERDOS COMPLEMENTARIOS / MEMORÁN- } \\
\text { DUMS / MECANISMOS DE COOPERACIÓN LABO- } \\
\text { RAL / DECLARACIONES CONJUNTAS / ANEXOS } \\
\text { (TiTULOS DE LOS ARTICULOS O APARTES) }\end{array}$ & $\begin{array}{l}\text { REFERENCIA A PRINCIPIOS Y DERECHOS FUNDAMENTALES } \\
\text { EN EL TRABAJO Y OTROS TEMAS } \\
\text { (TRANSCRIPCIÓN DE APARTES PERTINENTES) }\end{array}$ \\
\hline 3. Colombia-Chile & $\begin{array}{l}\text { TRATADO DE LIBRE COMERCIO } \\
\text { Firmado el } 27 \text { de noviembre de } \\
2006 \text { y vigente desde el } 8 \text { de } \\
\text { mayo de } 2009 . \\
\text { Capítulo } 17 \text { (Laboral): } \\
\text { Artículo 17.1: Compromisos } \\
\text { compartidos. } \\
\text { Artículo 17.2: Cumplimiento de } \\
\text { la legislación nacional. } \\
\text { Artículo 17.3: Cooperación la- } \\
\text { boral. } \\
\text { Artículo 17.4: Disposiciones ins- } \\
\text { titucionales. } \\
\text { Artículo 17.5: Definiciones }\end{array}$ & & $\begin{array}{l}\text { CAPítULo } 17 \text { (LABORAL): } \\
\text { Artículo 17.1: Compromisos compartidos. } \\
\text { 1. Las Partes reafirman sus obligaciones como } \\
\text { miembros de la Organización Internacional del } \\
\text { Trabajo (oIT) y sus compromisos asumidos en vir- } \\
\text { tud de la Declaración de la oit relativa a los Prin- } \\
\text { cipios y Derechos Fundamentales en el Trabajo } \\
\text { y su Seguimiento (1998). Cada Parte procurará } \\
\text { asegurar que tales principios, así como los dere- } \\
\text { chos establecidos en el artículo 17.5, sean reco- } \\
\text { nocidos y protegidos por su legislación nacional. } \\
\text { Artículo 17.3: Cooperación laboral. } \\
\text { 1. Las Partes reconocen la importancia de la coo- } \\
\text { peración bilateral para fortalecer las acciones en } \\
\text { materia laboral. En este sentido, las Partes con- } \\
\text { vienen en desarrollar actividades en las áreas de } \\
\text { cooperación enumeradas en el listado siguiente, } \\
\text { el cual no tiene carácter excluyente: (a) derechos }\end{array}$ \\
\hline
\end{tabular}




\begin{tabular}{|c|c|c|c|}
\hline PAises Signatarios & 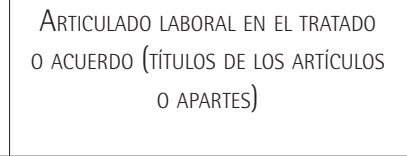 & $\begin{array}{l}\text { ACUERDOS COMPLEMENTARIOS / MEMORÁN- } \\
\text { DUMS / MECANISMOS DE COOPERACIÓN LABO- } \\
\text { RAL / DECLARACIONES CONJUNTAS / ANEXOS } \\
\text { (TiTULOS DE LOS ARTiCULOS O APARTES) }\end{array}$ & $\begin{array}{c}\text { REFERENCIA A PRINCIPIOS Y DERECHOS FUNDAMENTALES } \\
\text { EN EL TRABAJO Y OTROS TEMAS } \\
\text { (TRANSCRIPCIÓN DE APARTES PERTINENTES) }\end{array}$ \\
\hline 4. Chile-Canadá & $\begin{array}{l}\text { TRATADo de Libre Comercio (tLCCC) } \\
\text { Firmado el } 5 \text { de diciembre de } \\
1996 \text { y en vigencia desde el } 5 \text { de } \\
\text { julio de } 1997 .\end{array}$ & $\begin{array}{l}\text { ACUERDO DE COOPERACIÓN LABORAL y ANEXOS } \\
\text { Primera parte. Objetivos. } \\
\text { Artículo 1: Objetivos. } \\
\text { Segunda parte. Obligaciones. } \\
\text { Artículo 2: Compromiso general. }\end{array}$ & $\begin{array}{l}\text { ACUERDO DE COOPERACIÓN LABORAL } \\
\text { Preámbulo } \\
\text { El gobierno de Canadá y el gobierno de la Repú- } \\
\text { blica de Chile (Chile): RECORDANDo su determina- } \\
\text { ción, expresada en el Tratado de Libre Comercio } \\
\text { entre Canadá y Chile (TLCCC) de: [...] crear nuevas }\end{array}$ \\
\hline
\end{tabular}




\begin{tabular}{|c|c|c|c|}
\hline PAISES SIGNATARIOS & 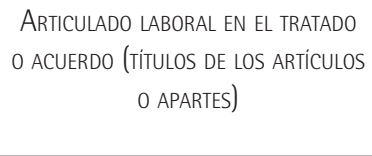 & $\begin{array}{l}\text { ACUERDOS COMPLEMENTARIOS / MEMORÁN- } \\
\text { DUMS / MECANISMOS DE COOPERACIÓN LABO- } \\
\text { RAL / DECLARACIONES CONJUNTAS / ANEXOS } \\
\text { (TitULOS DE LOS ARTICULOS O APARTES) }\end{array}$ & $\begin{array}{c}\text { REFERENCIA A PRINCIPIOS Y DERECHOS FUNDAMENTALES } \\
\text { EN EL TRABAJO Y OTROS TEMAS } \\
\text { (TRANSCRIPCIÓN DE APARTES PERTINENTES) }\end{array}$ \\
\hline
\end{tabular}




\begin{tabular}{|c|c|c|c|}
\hline PAISES SIGNATARIOS & 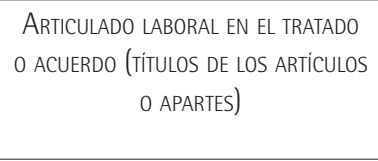 & $\begin{array}{l}\text { ACUERDOS COMPLEMENTARIOS / MEMORÁN- } \\
\text { DUMS / MECANISMOS DE COOPERACIÓN LABO- } \\
\text { RAL / DECLARACIONES CONJUNTAS / ANEXOS } \\
\text { (TíTULOS DE LOS ARTICULOS O APARTES) }\end{array}$ & $\begin{array}{c}\text { REFERENCIA A PRINCIPIOS Y DERECHOS FUNDAMENTALES } \\
\text { EN EL TRABAJO Y OTROS TEMAS } \\
\text { (TRANSCRIPCIÓN DE APARTES PERTINENTES) }\end{array}$ \\
\hline & & & $\begin{array}{l}\text { razones según establezcan las leyes internas de } \\
\text { cada Parte; (h) igual remuneración para hombres } \\
\text { y mujeres [...] } \\
\text { Anexo 1: Principios laborales } \\
\text { Los siguientes son lineamientos que las Partes se } \\
\text { comprometen a promover, conforme a las con- } \\
\text { diciones que establezca la legislación interna de } \\
\text { cada Parte, sin que constituyan normas comunes } \\
\text { mínimas para dicha legislación. Su propósito es } \\
\text { delimitar áreas amplias de atención en que las } \\
\text { Partes han desarrollado, cada una a su manera, } \\
\text { leyes, reglamentos, procedimientos y prácticas } \\
\text { que protegen los derechos y los intereses de sus } \\
\text { respectivas fuerzas laborales. } \\
\text { 1. Libertad de asociación y protección del de- } \\
\text { recho de organización. El derecho de los traba- } \\
\text { jadores, ejercido libremente y sin impedimento, } \\
\text { para establecer organizaciones y afiliarse a ellas } \\
\text { por elección propia, con el fin de impulsar y de- } \\
\text { fender sus intereses. } \\
\text { 2. Derecho a la negociación colectiva. La protec- } \\
\text { ción del derecho de los trabajadores organizados } \\
\text { a negociar libremente, en forma colectiva, los } \\
\text { términos y condiciones de empleo. } \\
\text { 3. Derecho de huelga. La protección del derecho } \\
\text { de huelga de los trabajadores con el fin de de- } \\
\text { fender sus intereses colectivos. }\end{array}$ \\
\hline
\end{tabular}




\begin{tabular}{|c|c|c|c|}
\hline PAISES SIGNATARIOS & 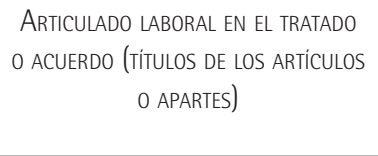 & $\begin{array}{l}\text { ACUERDOS COMPLEMENTARIOS / MEMORÁN- } \\
\text { DUMS / MECANISMOS DE COOPERACIÓN LABO- } \\
\text { RAL / DECLARACIONES CONJUNTAS / ANEXOS } \\
\text { (TitULOS DE LOS ARTICULOS O APARTES) }\end{array}$ & $\begin{array}{l}\text { REFERENCIA A PRINCIPIOS Y DERECHOS FUNDAMENTALES } \\
\text { EN EL TRABAJO Y OTROS TEMAS } \\
\text { (TRANSCRIPCIÓN DE APARTES PERTINENTES) }\end{array}$ \\
\hline
\end{tabular}




\begin{tabular}{|c|c|c|c|}
\hline Paises SIGNATARIOS & $\begin{array}{c}\text { ARTICULADO LABORAL EN EL TRATADO } \\
\text { O ACUERDO (TituLOS DE LOS ARTICULOS } \\
\text { O APARTES) }\end{array}$ & $\begin{array}{l}\text { ACUERDOS COMPLEMENTARIOS / MEMORÁN- } \\
\text { DUMS / MECANISMOS DE COOPERACIÓN LABO- } \\
\text { RAL / DECLARACIONES CONJUNTAS / ANEXOS } \\
\text { (TitULOS DE LOS ARTICULOS O APARTES) }\end{array}$ & $\begin{array}{c}\text { REFERENCIA A PRINCIPIOS Y DERECHOS FUNDAMENTALES } \\
\text { EN EL TRABAJO Y OTROS TEMAS } \\
\text { (TRANSCRIPCIÓN DE APARTES PERTINENTES) }\end{array}$ \\
\hline & & & $\begin{array}{l}\text { nables, como por ejemplo, cuando corresponda, } \\
\text { ciertos requisitos ocupacionales o calificaciones } \\
\text { laborales o ciertas prácticas establecidas o reglas } \\
\text { que rijan para la edad de jubilación, establecidas } \\
\text { de buena fe, además de las medidas especiales } \\
\text { de protección o de apoyo a grupos especificos, } \\
\text { que se han diseñado para contrarrestar los efec- } \\
\text { tos de la discriminación. } \\
\text { 8. Igual remuneración para hombres y mujeres. } \\
\text { Remuneración igual para hombres y mujeres de } \\
\text { acuerdo con el principio de pago igual por el } \\
\text { mismo trabajo realizado en un mismo estable- } \\
\text { cimiento [...]. }\end{array}$ \\
\hline 5. Chile-China & $\begin{array}{l}\text { TRATADO de Libre Comercio } \\
\text { Firmado el } 18 \text { de noviembre de } \\
2005 \text { y en vigencia desde el } 1 \text { de } \\
\text { octubre de } 2006 .\end{array}$ & $\begin{array}{l}\text { MEMORÁNDUM DE ENTENDIMIENTO DE COOPE- } \\
\text { RACIÓN LABORAL Y DE SEGURIDAD SOCIAL } \\
\text { Artículo 1: Actividades de coopera- } \\
\text { ción. } \\
\text { Artículo 2: Medios para la coopera- } \\
\text { ción entre las Partes. } \\
\text { Artículo 3: Coordinador de las activi- } \\
\text { dades de cooperación. } \\
\text { Artículo 4: Financiación para las ac- } \\
\text { tividades de cooperación. } \\
\text { Artículo 5: No afectación de dere- } \\
\text { chos. }\end{array}$ & $\begin{array}{l}\text { MEMORÁNDUM DE ENTENDIMIENTO DE COOPERACIÓN LABORAL } \\
\text { Y DE SEGURIDAD SOCIAL } \\
\text { [...] Considerando los objetivos de la Organiza- } \\
\text { ción Internacional del Trabajo, de la cual las Par- } \\
\text { tes son miembros [...]. } \\
\text { Artículo 1. Las Partes llevarán a cabo, de común } \\
\text { acuerdo, actividades de cooperación, particu- } \\
\text { larmente en las siguientes materias: a) políticas } \\
\text { de empleo y trabajo y diálogo social, incluyendo } \\
\text { trabajo decente, legislación laboral e inspección } \\
\text { del trabajo; b) mejoramiento de las condiciones } \\
\text { laborales y capacitación a los trabajadores; c) }\end{array}$ \\
\hline
\end{tabular}




\begin{tabular}{|c|c|c|c|}
\hline PAises SIGNATARIOS & 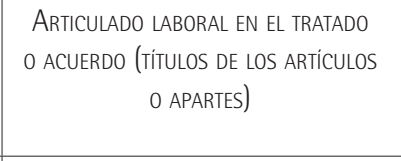 & $\begin{array}{c}\text { ACUERDOS COMPLEMENTARIOS / MEMORÁN- } \\
\text { DUMS / MECANISMOS DE COOPERACIÓN LABO- } \\
\text { RAL / DECLARACIONES CONJUNTAS / ANEXOS } \\
\text { (TiTULOS DE LOS ARTTCULOS O APARTES) }\end{array}$ & $\begin{array}{c}\text { REFERENCIA A PRINCIPIOS Y DERECHOS FUNDAMENTALES } \\
\text { EN EL TRABAJO Y OTROS TEMAS } \\
\text { (TRANSCRIPCIÓN DE APARTES PERTINENTES) }\end{array}$ \\
\hline 6. Chile-Estados Unidos & $\begin{array}{l}\text { TRATADO DE LIBRE COMERCIO } \\
\text { Firmado el } 6 \text { de junio de } 2003 \text { y } \\
\text { vigente desde el } 1 \text { de enero de } \\
2004 . \\
\text { Capítulo dieciocho (Trabajo): } \\
\text { Artículo 18.1: Declaración de } \\
\text { compromiso compartido. } \\
\text { Artículo 18.2: Fiscalización de la } \\
\text { legislación laboral. } \\
\text { Artículo 18.3: Garantías proce- } \\
\text { sales e información pública. } \\
\text { Artículo 18.4: Consejo de Asun- } \\
\text { tos Laborales. } \\
\text { Artículo 18.5: Mecanismo de } \\
\text { cooperación laboral. } \\
\text { Artículo 18.6: Consultas coope- } \\
\text { rativas. } \\
\text { Artículo 18.7: Lista de árbitros } \\
\text { laborales. } \\
\text { Artículo 18.8: Definiciones. }\end{array}$ & $\begin{array}{l}\text { MECANISMOS DE COOPERACIÓN LABORAL } \\
\text { (AneXo 18.5) } \\
\text { Establecimiento de un mecanismo } \\
\text { de cooperación laboral. } \\
\text { Organización y funciones principa- } \\
\text { les. } \\
\text { Actividades de cooperación. } \\
\text { Implementación de actividades de } \\
\text { cooperación. }\end{array}$ & $\begin{array}{l}\text { TRATADO DE LIBRE COMERCIO } \\
\text { Artículo 18.8: Definiciones. Para los efectos de } \\
\text { este capítulo: Legislación laboral significa leyes } \\
\text { o regulaciones de cada Parte, o disposiciones de } \\
\text { las mismas, que estén directamente relacionadas } \\
\text { con los siguientes derechos laborales interna- } \\
\text { cionalmente reconocidos: (a) el derecho de aso- } \\
\text { ciación; (b) el derecho de organizarse y negociar } \\
\text { colectivamente; (c) la prohibición del uso de } \\
\text { cualquier forma de trabajo forzoso u obligatorio; } \\
\text { (d) una edad mínima para el empleo de niños, y } \\
\text { la prohibición y eliminación de las peores formas } \\
\text { de trabajo infantil, y (e) condiciones aceptables } \\
\text { de trabajo respecto a salarios mínimos, horas de } \\
\text { trabajo y seguridad y salud ocupacional. } \\
\text { MecAnIsmos DE coopeRAción LABORAL (AnEXo 18.5) } \\
\text { Establecimiento de un mecanismo de coopera- } \\
\text { ción laboral: } \\
\text { 1. Reconociendo que la cooperación bilateral } \\
\text { proporciona a las Partes mayores oportunidades } \\
\text { para perfeccionar las normas laborales y para } \\
\text { progresar en compromisos comunes, incluyendo }\end{array}$ \\
\hline
\end{tabular}

* Como los artículos no tienen título, se agregó uno teniendo en cuenta el contenido de cada artículo. 


\begin{tabular}{|c|c|c|c|}
\hline PAises SIGNATARIOS & $\begin{array}{l}\text { ARTICULADO LABORAL EN EL TRATADO } \\
\text { O ACUERDO (TitulOS DE LOS ARTICULOS } \\
\text { O APARTES) }\end{array}$ & $\begin{array}{l}\text { ACUERDOS COMPLEMENTARIOS / MEMORÁN- } \\
\text { DUMS / MECANISMOS DE COOPERACIÓN LABO- } \\
\text { RAL / DECLARACIONES CONJUNTAS / ANEXOS } \\
\text { (TítULOS DE LOS ARTICULOS O APARTES) }\end{array}$ & $\begin{array}{c}\text { REFERENCIA A PRINCIPIOS Y DERECHOS FUNDAMENTALES } \\
\text { EN EL TRABAJO Y OTROS TEMAS } \\
\text { (TRANSCRIPCIÓN DE APARTES PERTINENTES) }\end{array}$ \\
\hline & & & $\begin{array}{l}\text { Ia Declaración de la oit relativa a los Principios y } \\
\text { Derechos Fundamentales en el Trabajo y su Se- } \\
\text { guimiento (1998), las Partes han establecido un } \\
\text { mecanismo de cooperación laboral. }\end{array}$ \\
\hline 7. Chile-Japón & $\begin{array}{l}\text { ACUERDO PARA UNA ASOCIACIÓn ECONÓ- } \\
\text { MICA ESTRATÉGICA } \\
\text { Firmado el } 27 \text { de marzo de } 2007 \\
\text { y en vigencia desde el } 3 \text { de sep- } \\
\text { tiembre de } 2007 .\end{array}$ & $\begin{array}{l}\text { DeCLARACIÓN CONJUNTA CON OCASIÓN DE LA } \\
\text { FIRMA DEL ACUERDO dE AsOCIACIÓN ECONÓ- } \\
\text { MICA ESTRATÉGICA } \\
\text { AnEXo } 4 \text { (RELACIONES labORALES) } \\
\text { 1. Reafirmación de obligaciones } \\
\text { como miembros de la oIT. } \\
\text { 2. Concordancia con los compromi- } \\
\text { sos adquiridos conforme a acuerdos } \\
\text { internacionales en materia laboral. } \\
\text { 3. No restricción encubierta de co- } \\
\text { mercio internacional. } \\
\text { 4. No aplicación de normas para } \\
\text { alentar comercio o inversiones. } \\
\text { 5. Conciencia pública sobre normas } \\
\text { laborales.* }\end{array}$ & $\begin{array}{l}\text { DECLARACIÓN CONJUNTA CON OCASIÓN DE LA FIRMA DEL } \\
\text { ACUERDO DE ASOCIACIÓN ECONÓMICA ESTRATÉGICA } \\
\text { Convencidos de la necesidad de proteger los } \\
\text { derechos laborales y de fortalecer las relaciones } \\
\text { comerciales y de inversión [...]. } \\
\text { Señalando que existen diferencias en las condi- } \\
\text { ciones sociales, culturales, económicas, tecnoló- } \\
\text { gicas y jurídicas de ambos paises [...]. } \\
\text { Conscientes de la importancia de tratar los te- } \\
\text { mas laborales sobre una base de cooperación, } \\
\text { consulta y diálogo; } \\
\text { Han confirmado lo siguiente: } \\
\text { 1. Ambos gobiernos reafirman las obligaciones } \\
\text { de sus respectivos paises en tanto miembros de } \\
\text { la Organización Internacional del Trabajo (oit) y } \\
\text { su compromiso con los principios de la Declara- } \\
\text { ción de la oit relativos a los Principios y Derechos } \\
\text { Fundamentales en el Trabajo y su Seguimiento } \\
\text { (1998) [...]. } \\
\text { Ambos gobiernos comparten su postura sobre la } \\
\text { importancia de que las leyes, normas, políticas y }\end{array}$ \\
\hline
\end{tabular}

* Como los artículos no tienen título, se agregó uno teniendo en cuenta el contenido de cada artículo. 


\begin{tabular}{|c|c|c|c|}
\hline Paises SIGNATARIOS & 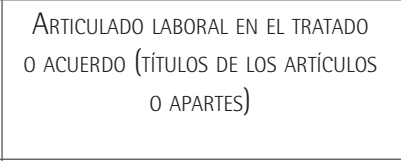 & $\begin{array}{l}\text { ACUERDOS COMPLEMENTARIOS / MEMORÁN- } \\
\text { DUMS / MECANISMOS DE COOPERACIÓN LABO- } \\
\text { RAL / DECLARACIONES CONJUNTAS / ANEXOS } \\
\text { (TitULOS DE LOS ARTICULOS O APARTES) }\end{array}$ & $\begin{array}{c}\text { REFERENCIA A PRINCIPIOS Y DERECHOS FUNDAMENTALES } \\
\text { EN EL TRABAJO Y OTROS TEMAS } \\
\text { (TRANSCRIPCIÓN DE APARTES PERTINENTES) }\end{array}$ \\
\hline & & & $\begin{array}{l}\text { prácticas laborales de sus respectivos países es- } \\
\text { tén en concordancia con los compromisos con- } \\
\text { traídos por sus respectivos países conforme a los } \\
\text { acuerdos internacionales en materia laboral [...]. }\end{array}$ \\
\hline $\begin{array}{l}\text { 8. Chile, Brunei Darussalam, } \\
\text { Nueva Zelandia y Singapur }\end{array}$ & $\begin{array}{l}\text { Acuerdo Estratégico Transpacifico de } \\
\text { Asociación Económica } \\
\text { Firmado el } 18 \text { de julio de } 2005 \\
\text { y vigente desde el } 8 \text { de noviem- } \\
\text { bre de } 2006 \text { (Chile), desde el } 12 \\
\text { de julio de } 2006 \text { (Brunei Darus- } \\
\text { salam), desde el } 28 \text { de mayo de } \\
2006 \text { (Nueva Zelandia) y del } 28 \\
\text { de mayo de } 2006 \text { (Singapur). }\end{array}$ & $\begin{array}{l}\text { MEMORÁNDUM DE ENTENDIMIENTO SOBRE } \\
\text { COOPERACIÓN LABORAL } \\
\text { Artículo 1: Objetivos. } \\
\text { Artículo 2: Elementos principales/ } \\
\text { compromisos. } \\
\text { Artículo 3: Cooperación. } \\
\text { Artículo 4: Disposiciones institucio- } \\
\text { nales. } \\
\text { Artículo 5: Consultas. } \\
\text { Artículo 6: Disposiciones finales. }\end{array}$ & $\begin{array}{l}\text { MEMORÁNDUM DE ENTENDIMIENTO SOBRE COOPERACIÓN LA- } \\
\text { BORAL } \\
\text { [...] Recordando nuestra resolución de mejorar } \\
\text { las condiciones laborales y niveles de vida en } \\
\text { nuestros respectivos paises y de proteger, mejo- } \\
\text { rar y de hacer cumplir los derechos básicos de los } \\
\text { trabajadores, considerando los diversos niveles } \\
\text { de desarrollo nacional [...]. } \\
\text { Compartiendo la común aspiración de que el } \\
\text { libre comercio y las inversiones deberian condu- } \\
\text { cirnos a la creación de empleo, al trabajo decente } \\
\text { y a trabajos significativos para los trabajadores, } \\
\text { con términos y condiciones de empleo de acuer- } \\
\text { do a los principios laborales fundamentales de la } \\
\text { Organización Internacional del Trabajo (oit). } \\
\text { Artículo 1: Objetivos } \\
\text { Los objetivos de las Partes serán: promover una } \\
\text { mejor comprensión y observancia de los princi- } \\
\text { pios incorporados en la Declaración de la oit re- } \\
\text { lativa a los Principios y Derechos Fundamentales } \\
\text { en el Trabajo y su Seguimiento (1998). } \\
\text { Artículo 2: Elementos principales/compromisos. }\end{array}$ \\
\hline
\end{tabular}




\begin{tabular}{|c|c|c|c|}
\hline Paises SIGNATARIOS & $\begin{array}{l}\text { ARTiCULADO LABORAL EN EL TRATADO } \\
\text { O ACUERDO (titulOS DE LOS ARTICULOS } \\
\text { 0 APARTES) }\end{array}$ & $\begin{array}{l}\text { ACUERDOS COMPLEMENTARIOS / MEMORÁN- } \\
\text { DUMS / MECANISMOS DE COOPERACIÓN LABO- } \\
\text { RAL / DECLARACIONES CONJUNTAS / ANEXOS } \\
\text { (TitULOS DE LOS ARTICULOS O APARTES) }\end{array}$ & $\begin{array}{c}\text { REFERENCIA A PRINCIPIOS Y DERECHOS FUNDAMENTALES } \\
\text { EN EL TRABAJO Y OTROS TEMAS } \\
\text { (TRANSCRIPCIÓN DE APARTES PERTINENTES) }\end{array}$ \\
\hline & & & $\begin{array}{l}\text { 1. Las Partes que son miembros de la olt confir- } \\
\text { man sus obligaciones en tal carácter. } \\
\text { 2. Las Partes declaran formalmente su compro- } \\
\text { miso con los principios de la Declaración de la oıт } \\
\text { relativa a los Principios y Derechos Fundamen- } \\
\text { tales en el Trabajo y su Seguimiento (1998) [...]. }\end{array}$ \\
\hline 9. Chile-Perú & $\begin{array}{l}\text { ACUERDO DE LIBRE COMERCIO } \\
\text { Firmado el } 22 \text { de agosto de } 2006 \\
\text { y vigente desde el } 1 \text { de marzo de } \\
2009 .\end{array}$ & $\begin{array}{l}\text { MeMORÁNDUM DE ENTENDIMIENTO SOBRE } \\
\text { COOPERACIÓn LABORAL y MIGRATORIA } \\
\text { Preámbulo. } \\
\text { Artículo 1: Objetivos. } \\
\text { Artículo 2: Compromisos comparti- } \\
\text { dos. } \\
\text { Artículo 3: Cumplimiento de la legis- } \\
\text { lación nacional. } \\
\text { Artículo 4: Disposiciones institucio- } \\
\text { nales. } \\
\text { Artículo 5: Cooperación. } \\
\text { Artículo 6: Definiciones. } \\
\text { Artículo 7: Vigencia. }\end{array}$ & $\begin{array}{l}\text { MEMORÁNDUM DE ENTENDIMIENTO SOBRE COOPERACIÓN LA- } \\
\text { BORAL Y MIGRATORIA } \\
\text { [...] Subrayando su determinación, en orden a } \\
\text { crear nuevos y mejores empleos de calidad para } \\
\text { sus trabajadores y aumentar los niveles de vida } \\
\text { en sus respectivos territorios; proteger, ampliar } \\
\text { y hacer efectivos los derechos fundamentales de } \\
\text { los trabajadores; y proteger y hacer efectivos los } \\
\text { derechos de los trabajadores migratorios [...]. } \\
\text { Artículo 2: Compromisos compartidos. } \\
\text { 1. Las Partes reafirman sus obligaciones como } \\
\text { miembros de la Organización Internacional del } \\
\text { Trabajo (oit) y sus compromisos asumidos en } \\
\text { virtud de la Declaración de la olt relativa a los } \\
\text { Principios y Derechos Fundamentales en el Tra- } \\
\text { bajo y su Seguimiento (1998) y de la Convención } \\
\text { Internacional sobre la Protección de los Dere- } \\
\text { chos de todos los Trabajadores Migratorios y de } \\
\text { sus Familiares, de Naciones Unidas (1990). Cada } \\
\text { Parte procurará asegurar que tales principios, así }\end{array}$ \\
\hline
\end{tabular}




\begin{tabular}{|c|c|c|c|}
\hline Paises signatarios & 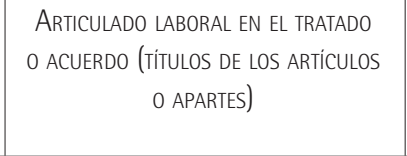 & $\begin{array}{l}\text { ACUERDOS COMPLEMENTARIOS / MEMORÁN- } \\
\text { DUMS / MECANISMOS DE COOPERACIÓN LABO- } \\
\text { RAL / DECLARACIONES CONJUNTAS / ANEXOS } \\
\text { (TitULOS DE LOS ARTICULOS O APARTES) }\end{array}$ & $\begin{array}{l}\text { REFERENCIA A PRINCIPIOS Y DERECHOS FUNDAMENTALES } \\
\text { EN EL TRABAJO Y OTROS TEMAS } \\
\text { (TRANSCRIPCIÓN DE APARTES PERTINENTES) }\end{array}$ \\
\hline 10. Costa Rica-Canadá & $\begin{array}{l}\text { TRATADO DE LiBRE Comercio } \\
\text { Firmado el } 23 \text { de abril de } 2001 \\
\text { y en vigencia desde el } 1 \text { de no- } \\
\text { viembre de } 2002 .\end{array}$ & $\begin{array}{l}\text { ACUERDO DE COOPERACIÓN LABORAL } \\
\text { Con sus anexos } 1 \text { (Principios y de- } \\
\text { rechos fundamentales en el trabajo) } \\
\text { y } 2 \text { (Principios y derechos laborales } \\
\text { adicionales). }\end{array}$ & $\begin{array}{l}\text { ACUERDO DE COOPERACIÓN LABORAL } \\
\text { REAFIRMANDO que ambos países son miembros de la } \\
\text { Organización Internacional del Trabajo (oIT) [...]. } \\
\text { Primera parte: Objetivos. }\end{array}$ \\
\hline
\end{tabular}




\begin{tabular}{|c|c|c|c|}
\hline PAises SIGNATARIOS & 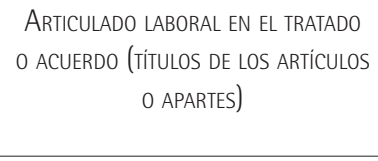 & $\begin{array}{l}\text { ACUERDOS COMPLEMENTARIOS / MEMORÁN- } \\
\text { DUMS / MECANISMOS DE COOPERACIÓN LABO- } \\
\text { RAL / DECLARACIONES CONJUNTAS / ANEXOS } \\
\text { (TíTULOS DE LOS ARTICULOS O APARTES) }\end{array}$ & $\begin{array}{l}\text { REFERENCIA A PRINCIPIOS Y DERECHOS FUNDAMENTALES } \\
\text { EN EL TRABAJO Y OTROS TEMAS } \\
\text { (TRANSCRIPCIÓN DE APARTES PERTINENTES) }\end{array}$ \\
\hline & & $\begin{array}{l}\text { Artículo 1: Objetivos. } \\
\text { Artículo 2: Compromisos generales. } \\
\text { Artículo 3: Ámbito de aplicación del } \\
\text { acuerdo. } \\
\text { Artículo 4: Medidas de aplicación } \\
\text { gubernamental. } \\
\text { Artículo 5: Medidas privadas. } \\
\text { Artículo 6: Garantías procesales. } \\
\text { Artículo 7: Publicación. } \\
\text { Artículo 8: Información pública [...]. }\end{array}$ & 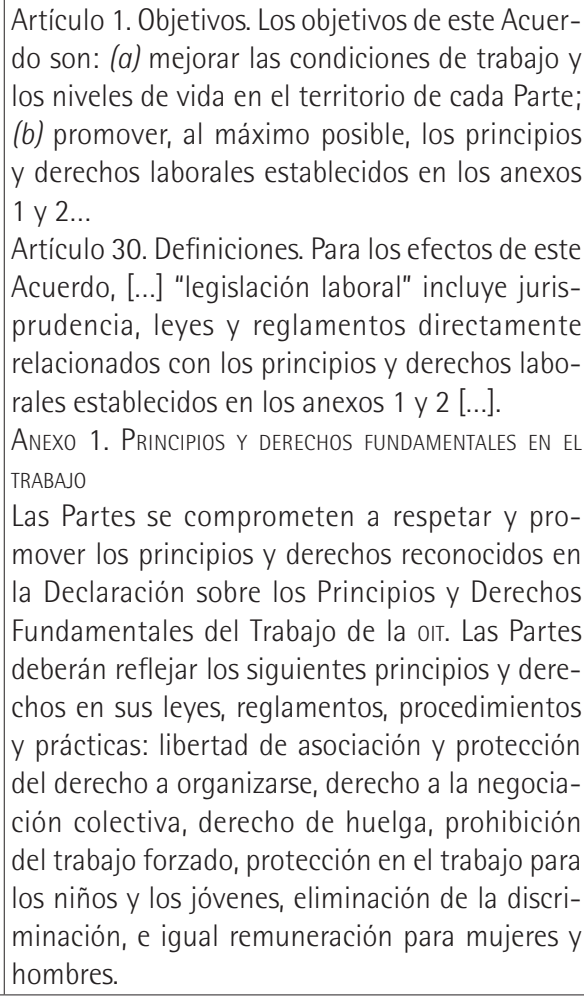 \\
\hline
\end{tabular}




\begin{tabular}{|c|c|c|c|}
\hline Paises Signatarios & 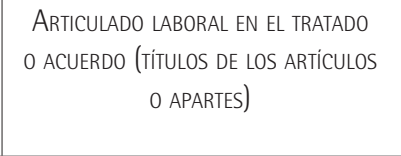 & $\begin{array}{l}\text { ACUERDOS COMPLEMENTARIOS / MEMORÁN- } \\
\text { DUMS / MECANISMOS DE COOPERACIÓN LABO- } \\
\text { RAL / DECLARACIONES CONJUNTAS / ANEXOS } \\
\text { (TiTULOS DE LOS ARTICULOS O APARTES) }\end{array}$ & $\begin{array}{c}\text { REFERENCIA A PRINCIPIOS Y DERECHOS FUNDAMENTALES } \\
\text { EN EL TRABAJO Y OTROS TEMAS } \\
\text { (TRANSCRIPCIÓN DE APARTES PERTINENTES) }\end{array}$ \\
\hline
\end{tabular}




\begin{tabular}{|c|c|c|c|}
\hline PAises SIGNATARIOS & 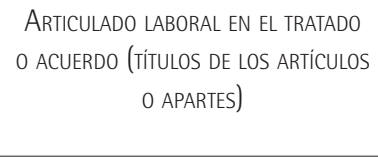 & $\begin{array}{l}\text { ACUERDOS COMPLEMENTARIOS / MEMORÁN- } \\
\text { DUMS / MECANISMOS DE COOPERACIÓN LABO- } \\
\text { RAL / DECLARACIONES CONJUNTAS / ANEXOS } \\
\text { (TíTULOS DE LOS ARTICULOS O APARTES) }\end{array}$ & $\begin{array}{l}\text { REFERENCIA A PRINCIPIOS Y DERECHOS FUNDAMENTALES } \\
\text { EN EL TRABAJO Y OTROS TEMAS } \\
\text { (TRANSCRIPCIÓN DE APARTES PERTINENTES) }\end{array}$ \\
\hline & & $\begin{array}{l}\text { Artículo 13: Funciones del Secreta- } \\
\text { riado. } \\
\text { Artículo 14: Estudios e informes del } \\
\text { Secretariado. } \\
\text { Sección c. Oficinas administrativas } \\
\text { nacionales. } \\
\text { Artículo 15: Estructura de la Oficina } \\
\text { Administrativa Nacional. } \\
\text { Artículo 16: Funciones de la Oficina } \\
\text { Administrativa Nacional. } \\
\text { Sección D: Comités nacionales. } \\
\text { Artículo 17: Comités consultivos na- } \\
\text { cionales. } \\
\text { Artículo 18: Comités gubernamen- } \\
\text { tales. } \\
\text { Sección E. Idiomas oficiales. } \\
\text { Artículo 19: Idiomas oficiales. } \\
\text { Cuarta parte. Consultas y evaluacio- } \\
\text { nes para la cooperación. } \\
\text { Artículo 20: Cooperación. } \\
\text { Sección A. Consultas para la coope- } \\
\text { ración. } \\
\text { Artículo 21: Consultas entre las ofici- } \\
\text { nas administrativas nacionales. } \\
\text { Artículo 22: Consultas ministeriales. } \\
\text { Sección B: Evaluaciones. }\end{array}$ & $\begin{array}{l}\text { cha legislación. Su propósito es delimitar áreas } \\
\text { amplias de atención en que las Partes han desa- } \\
\text { rrollado, cada una a su manera, leyes, reglamen- } \\
\text { tos, procedimientos y prácticas que protegen } \\
\text { los derechos y los intereses de sus respectivas } \\
\text { fuerzas de trabajo. } \\
\text { 1. Libertad de asociación y protección del de- } \\
\text { recho a organizarse. El derecho de los trabaja- } \\
\text { dores, ejercido libremente y sin impedimento } \\
\text { para instituir organizaciones y unirse a ellas por } \\
\text { elección propia, con el fin de impulsar y defender } \\
\text { sus intereses. } \\
\text { 2. Derecho a la negociación colectiva. La protec- } \\
\text { ción del derecho de los trabajadores organizados } \\
\text { a negociar libremente, en forma colectiva, los } \\
\text { términos y condiciones de empleo. } \\
\text { 3. Derecho de huelga. La protección del derecho } \\
\text { de huelga de los trabajadores, con el fin de de- } \\
\text { fender sus intereses colectivos. } \\
\text { 4. Prohibición del trabajo forzado. } \\
\text { 5. La prohibición y abolición de todas las formas } \\
\text { de trabajo forzado u obligatorio, excepto tipos } \\
\text { de trabajo obligatorio en casos generalmente } \\
\text { aceptados por las Partes, tales como: el servicio } \\
\text { militar obligatorio, ciertas obligaciones civicas, } \\
\text { el trabajo en las prisiones sin que sea para pro- }\end{array}$ \\
\hline
\end{tabular}




\begin{tabular}{|c|c|c|c|}
\hline Paises Signatarios & 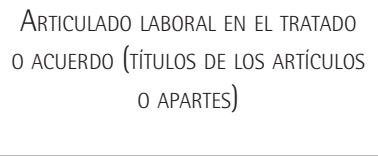 & $\begin{array}{l}\text { ACUERDOS COMPLEMENTARIOS / MEMORÁN- } \\
\text { DUMS / MECANISMOS DE COOPERACIÓN LABO- } \\
\text { RAL / DECLARACIONES CONJUNTAS / ANEXOS } \\
\text { (TitULOS DE LOS ARTICULOS O APARTES) }\end{array}$ & $\begin{array}{c}\text { REFERENCIA A PRINCIPIOS Y DERECHOS FUNDAMENTALES } \\
\text { EN EL TRABAJO Y OTROS TEMAS } \\
\text { (TRANSCRIPCIÓN DE APARTES PERTINENTES) }\end{array}$ \\
\hline & & $\begin{array}{l}\text { Artículo 23: Comité Evaluador de } \\
\text { Expertos. } \\
\text { Artículo 24: Reglas de procedimien- } \\
\text { to. } \\
\text { Artículo 25: Proyectos de informes } \\
\text { de evaluación. } \\
\text { Artículo 26: Informes de evaluación } \\
\text { finales. } \\
\text { Quinta parte. Solución de contro- } \\
\text { versias. } \\
\text { Artículo 27: Consultas. } \\
\text { Artículo 28: Inicio del procedimiento. } \\
\text { Artículo 29: Solicitud de integración } \\
\text { de un panel arbitral. } \\
\text { Artículo 30: Lista de panelistas. } \\
\text { Artículo 31: Requisitos para ser pa- } \\
\text { nelista. } \\
\text { Artículo 32: Selección del panel. } \\
\text { Artículo 33: Reglas de procedimien- } \\
\text { to. } \\
\text { Artículo 34: Participación de la ter- } \\
\text { cera Parte. } \\
\text { Artículo 35: Función de los expertos. } \\
\text { Artículo 36: Informe preliminar. } \\
\text { Artículo 37: Informe final. }\end{array}$ & $\begin{array}{l}\text { pósitos privados, y el trabajo requerido en casos } \\
\text { de emergencia. } \\
\text { 6. Restricciones sobre el trabajo de menores. El } \\
\text { establecimiento de restricciones sobre el trabajo } \\
\text { de menores que podrán variar al tomar en con- } \\
\text { sideración factores capaces de afectar el desa- } \\
\text { rrollo pleno de las facultades físicas, mentales y } \\
\text { morales de los jóvenes, incluyendo sus necesida- } \\
\text { des de educación y de seguridad. } \\
\text { 7. Condiciones mínimas de trabajo. El estableci- } \\
\text { miento de condiciones mínimas de trabajo, tales } \\
\text { como salario mínimo y pago de tiempo extra, } \\
\text { para los trabajadores asalariados, incluyendo a } \\
\text { quienes no están protegidos por un contrato } \\
\text { colectivo. } \\
\text { 8. Eliminación de la discriminación en el empleo. } \\
\text { Eliminación de la discriminación en el empleo } \\
\text { por causa de raza, sexo, religión, edad u otros } \\
\text { conceptos, con la salvedad de ciertas excepcio- } \\
\text { nes razonables, tales como, en su caso, requisitos } \\
\text { o acreditaciones para el empleo, así como prácti- } \\
\text { cas establecidas o reglas que rijan las edades de } \\
\text { retiro que se establezcan de buena fe, y medidas } \\
\text { especiales de protección o de apoyo a grupos } \\
\text { particulares, diseñadas para contrarrestar los } \\
\text { efectos de la discriminación. }\end{array}$ \\
\hline
\end{tabular}




\begin{tabular}{|c|c|c|c|}
\hline PAISES SIGNATARIOS & 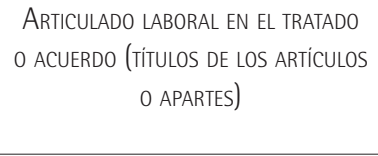 & $\begin{array}{l}\text { ACUERDOS COMPLEMENTARIOS / MEMORÁN- } \\
\text { DUMS / MECANISMOS DE COOPERACIÓN LABO- } \\
\text { RAL / DECLARACIONES CONJUNTAS / ANEXOS } \\
\text { (TitULOS DE LOS ARTICULOS O APARTES) }\end{array}$ & $\begin{array}{l}\text { REFERENCIA A PRINCIPIOS Y DERECHOS FUNDAMENTALES } \\
\text { EN EL TRABAJO Y OTROS TEMAS } \\
\text { (TRANSCRIPCIÓN DE APARTES PERTINENTES) }\end{array}$ \\
\hline & & $\begin{array}{l}\text { Artículo 38: Cumplimiento del infor- } \\
\text { me final. } \\
\text { Artículo 39: Revisión del cumpli- } \\
\text { miento. } \\
\text { Artículo 40: Procedimientos adicio- } \\
\text { nales. } \\
\text { Sexta parte. Disposiciones generales. } \\
\text { Artículo 42: Principios para la aplica- } \\
\text { ción de la legislación laboral. } \\
\text { Artículo 43: Derechos de particula- } \\
\text { res. } \\
\text { Artículo 44: Protección de informa- } \\
\text { ción. } \\
\text { Artículo 45: Cooperación con la olt. } \\
\text { Artículo 46: Extensión de las obliga- } \\
\text { ciones. } \\
\text { Artículo 47: Financiamiento de la } \\
\text { Comisión. } \\
\text { Artículo 48: Privilegios e inmunida- } \\
\text { des. } \\
\text { Artículo 49: Definiciones. } \\
\text { Séptima parte. Disposiciones finales. } \\
\text { Artículo 50: Anexos. } \\
\text { Anexo 1: Principios laborales. }\end{array}$ & $\begin{array}{l}\text { 9. Salario igual para hombres y mujeres. Salarios } \\
\text { iguales para hombres y mujeres, según el princi- } \\
\text { pio de pago igual por trabajo igual en un mismo } \\
\text { establecimiento [...]. }\end{array}$ \\
\hline
\end{tabular}




\begin{tabular}{|c|c|c|c|}
\hline PAISES SIGNATARIOS & 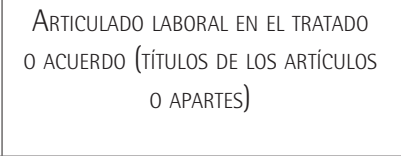 & $\begin{array}{l}\text { ACUERDOS COMPLEMENTARIOS / MEMORÁN- } \\
\text { DUMS / MECANISMOS DE COOPERACIÓN LABO- } \\
\text { RAL / DECLARACIONES CONJUNTAS / ANEXOS } \\
\text { (TiTULOS DE LOS ARTICULOS O APARTES) }\end{array}$ & $\begin{array}{c}\text { REFERENCIA A PRINCIPIOS Y DERECHOS FUNDAMENTALES } \\
\text { EN EL TRABAJO Y OTROS TEMAS } \\
\text { (TRANSCRIPCIÓN DE APARTES PERTINENTES) }\end{array}$ \\
\hline
\end{tabular}




\begin{tabular}{|c|c|c|c|}
\hline Paises Signatarios & 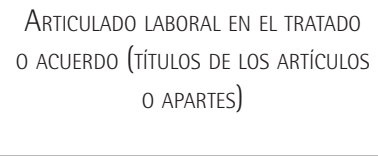 & $\begin{array}{l}\text { ACUERDOS COMPLEMENTARIOS / MEMORÁN- } \\
\text { DUMS / MECANISMOS DE COOPERACIÓN LABO- } \\
\text { RAL / DECLARACIONES CONJUNTAS / ANEXOS } \\
\text { (TitULLOS DE LOS ARTICULOS O APARTES) }\end{array}$ & $\begin{array}{c}\text { REFERENCIA A PRINCIPIOS Y DERECHOS FUNDAMENTALES } \\
\text { EN EL TRABAJO Y OTROS TEMAS } \\
\text { (TRANSCRIPCIÓN DE APARTES PERTINENTES) }\end{array}$ \\
\hline & & & $\begin{array}{l}\text { dores, ejercido libremente y sin impedimento, } \\
\text { para instituir organizaciones y unirse a ellas por } \\
\text { elección propia, con el fin de impulsar y defender } \\
\text { sus intereses. } \\
\text { 2. Derecho a la negociación colectiva. La protec- } \\
\text { ción del derecho de los trabajadores organizados } \\
\text { a negociar libremente, en forma colectiva, los } \\
\text { términos y condiciones de empleo. } \\
\text { 3. Derecho de huelga. La protección del derecho } \\
\text { de huelga de los trabajadores, con el fin de de- } \\
\text { fender sus intereses colectivos. } \\
\text { 4. Prohibición del trabajo forzado. La prohibición } \\
\text { y abolición de todas las formas de trabajo forza- } \\
\text { do u obligatorio, excepto tipos de trabajo obli- } \\
\text { gatorio en casos generalmente aceptados por las } \\
\text { Partes, tales como: el servicio militar obligatorio, } \\
\text { ciertas obligaciones cívicas, el trabajo en las pri- } \\
\text { siones sin que sea para propósitos privados, y el } \\
\text { trabajo requerido en casos de emergencia. } \\
\text { 5. Restricciones sobre el trabajo de menores. El } \\
\text { establecimiento de restricciones sobre el trabajo } \\
\text { de menores que podrán variar al tomar en con- } \\
\text { sideración factores capaces de afectar el desa- } \\
\text { rrollo pleno de las facultades físicas, mentales y } \\
\text { morales de los jóvenes, incluyendo sus necesida- } \\
\text { des de educación y de seguridad. }\end{array}$ \\
\hline
\end{tabular}




\begin{tabular}{|c|c|c|c|}
\hline Paises Signatarios & 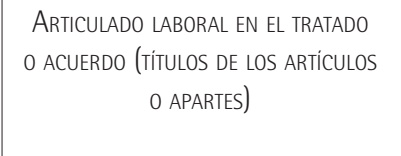 & $\begin{array}{l}\text { ACUERDOS COMPLEMENTARIOS / MEMORÁN- } \\
\text { DUMS / MECANISMOS DE COOPERACIÓN LABO- } \\
\text { RAL / DECLARACIONES CONJUNTAS / ANEXOS } \\
\text { (TitULOS DE LOS ARTICULOS O APARTES) }\end{array}$ & $\begin{array}{c}\text { REFERENCIA A PRINCIPIOS Y DERECHOS FUNDAMENTALES } \\
\text { EN EL TRABAJO Y OTROS TEMAS } \\
\text { (TRANSCRIPCIÓN DE APARTES PERTINENTES) }\end{array}$ \\
\hline & & & $\begin{array}{l}\text { 6. Condiciones mínimas de trabajo. El estableci- } \\
\text { miento de condiciones minimas de trabajo, tales } \\
\text { como salario mínimo y pago de tiempo extra, } \\
\text { para los trabajadores asalariados, incluyendo a } \\
\text { quienes no están protegidos por un contrato } \\
\text { colectivo. } \\
\text { 7. Eliminación de la discriminación en el empleo. } \\
\text { ANEXo 18.05. MECANISMOS DE COOPERACIÓN LABORAL Y } \\
\text { DESARROLLO DE CAPACIDADES }\end{array}$ \\
\hline 13. Panamá-Estados Unidos & $\begin{array}{l}\text { TRATADO DE PROMoción COMERCIAL } \\
\text { Firmado el } 28 \text { de junio de } 2007 \text { y } \\
\text { en vigencia desde el } 31 \text { de octu- } \\
\text { bre de } 2012 . \\
\text { Capitulo 16 (Laboral): } \\
\text { Artículo 16.1: Declaración de } \\
\text { compromiso compartido. } \\
\text { Artículo 16.2: Derechos laborales } \\
\text { fundamentales. } \\
\text { Artículo 16.3: Aplicación de la } \\
\text { legislación laboral. } \\
\text { Artículo 16.4: Garantías proce- } \\
\text { sales e información pública. } \\
\text { Artículo 16.5: Estructura insti- } \\
\text { tucional. } \\
\text { Artículo 16.6: Mecanismo de } \\
\text { cooperación laboral y desarrollo } \\
\text { de capacidades. }\end{array}$ & $\begin{array}{l}\text { ANEXO } 16.6 \text { (MECANISMO DE COOPERACIÓN } \\
\text { LABORAL Y DESARROLLO DE CAPACIDADES) } \\
\text { Organización y funciones principa- } \\
\text { les. } \\
\text { Prioridades de cooperación y desa- } \\
\text { rrollo de capacidades. } \\
\text { Implementación de las actividades } \\
\text { de cooperación. } \\
\text { Participación pública. }\end{array}$ & $\begin{array}{l}\text { CAPiTULo } 16 \text { (LABORAL) } \\
\text { Artículo 16.1: Declaración de compromiso com- } \\
\text { partido. } \\
\text { Las Partes reafirman sus obligaciones como } \\
\text { miembros de la Organización Internacional del } \\
\text { Trabajo (ort). } \\
\text { Artículo 16.2: Derechos laborales fundamentales. } \\
\text { 1. Cada Parte adoptará y mantendrá en sus leyes } \\
\text { y reglamentos, y su correspondiente aplicación, } \\
\text { los siguientes derechos, tal como se definen en } \\
\text { la Declaración relativa a los Principios y Derechos } \\
\text { Fundamentales en el Trabajo y su Seguimiento } \\
\text { (1998) (Declaración de la oıt). } \\
\text { (a) La libertad de asociación; } \\
\text { (b) El reconocimiento efectivo del derecho a la } \\
\text { negociación colectiva; } \\
\text { (c) La eliminación de toda forma de trabajo for- } \\
\text { zoso u obligatorio; }\end{array}$ \\
\hline
\end{tabular}




\begin{tabular}{|c|c|c|c|}
\hline PAISES SIgnatarios & $\begin{array}{l}\text { ARTICULADO LABORAL EN EL TRATADO } \\
\text { O ACUERDO (titulOS DE LOS ARTICULOS } \\
\text { 0 APARTES) }\end{array}$ & $\begin{array}{l}\text { ACUERDOS COMPLEMENTARIOS / MEMORÁN- } \\
\text { DUMS / MECANISMOS DE COOPERACIÓN LABO- } \\
\text { RAL / DECLARACIONES CONJUNTAS / ANEXOS } \\
\text { (TítULOS DE LOS ARTICULOS O APARTES) }\end{array}$ & $\begin{array}{c}\text { REFERENCIA A PRINCIPIOS Y DERECHOS FUNDAMENTALES } \\
\text { EN EL TRABAJO Y OTROS TEMAS } \\
\text { (TRANSCRIPCIÓN DE APARTES PERTINENTES) }\end{array}$ \\
\hline & $\begin{array}{l}\text { Artículo 16.7: Consultas labora- } \\
\text { les cooperativas. } \\
\text { Artículo 16.8: Lista laboral. } \\
\text { Artículo 16.9: Definiciones. }\end{array}$ & & $\begin{array}{l}\text { (d) La abolición efectiva del trabajo infantil y, } \\
\text { para fines de este Tratado, la prohibición de las } \\
\text { peores formas de trabajo infantil, y } \\
\text { (e) La eliminación de la discriminación con res- } \\
\text { pecto al empleo y la ocupación. }\end{array}$ \\
\hline 14. Perú-Estados Unidos & $\begin{array}{l}\text { ACUERDO DE PROMOCIÓN COMERCIAL } \\
\text { Firmado el } 12 \text { de abril de } 2006 \text { y } \\
\text { en vigencia desde el } 1 \text { de febrero } \\
\text { de } 2009 . \\
\text { Capítulo } 17 \text { (Laboral): } \\
\text { Artículo 17.1: Declaración de } \\
\text { compromisos compartidos. } \\
\text { Artículo 17.2: Derechos laborales } \\
\text { fundamentales. } \\
\text { Artículo 17.3: Aplicación de la } \\
\text { legislación laboral. } \\
\text { Artículo 17.4: Garantías proce- } \\
\text { sales e información pública. } \\
\text { Artículo 17.5: Estructura insti- } \\
\text { tucional. } \\
\text { Artículo 17.6: Mecanismo de } \\
\text { cooperación laboral y desarrollo } \\
\text { de capacidades. } \\
\text { Artículo 17.7: Consultas labora- } \\
\text { les cooperativas. } \\
\text { Artículo 17.8: Definiciones. }\end{array}$ & $\begin{array}{l}\text { ANEXO 17.6 (MECANISMO DE COOPERACIÓN } \\
\text { LABORAL y DESARROLLO DE CAPACIDADES) } \\
\text { 1. Coordinación y supervisión. } \\
\text { 2. Prioridades de cooperación y de- } \\
\text { sarrollo de capacidades. } \\
\text { 3. Implementación de actividades de } \\
\text { cooperación. } \\
\text { 4. Participación pública. }\end{array}$ & $\begin{array}{l}\text { CAPítulo } 17 \text { (LABORAL): } \\
\text { Artículo 17.1: Declaración de compromisos com- } \\
\text { partidos. Las Partes reafirman sus obligaciones } \\
\text { como miembros de la Organización Internacio- } \\
\text { nal del Trabajo (oIT). } \\
\text { Artículo 17.2: Derechos laborales fundamentales. } \\
\text { 1. Cada Parte adoptará y mantendrá en sus leyes } \\
\text { y reglamentos, y su correspondiente aplicación, } \\
\text { los siguientes derechos, tal como se establecen } \\
\text { en la Declaración relativa a los Principios y De- } \\
\text { rechos Fundamentales en el Trabajo y su Segui- } \\
\text { miento (1998) (Declaración de la oit): } \\
\text { (a) La libertad de asociación; } \\
\text { (b) El reconocimiento efectivo del derecho a la } \\
\text { negociación colectiva; } \\
\text { (c) La eliminación de toda forma de trabajo for- } \\
\text { zoso u obligatorio; } \\
\text { (d) La abolición efectiva del trabajo infantil y, } \\
\text { para fines de este Acuerdo, la prohibición de las } \\
\text { peores formas de trabajo infantil, y } \\
\text { (e) La eliminación de la discriminación con res- } \\
\text { pecto a empleo y ocupación. }\end{array}$ \\
\hline
\end{tabular}




\begin{tabular}{|c|c|c|c|}
\hline PAISES SIGNATARIOS & 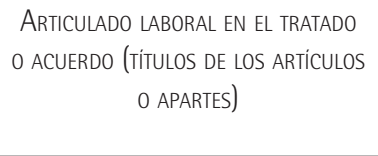 & $\begin{array}{l}\text { ACUERDOS COMPLEMENTARIOS / MEMORÁN- } \\
\text { DUMS / MECANISMOS DE COOPERACIÓN LABO- } \\
\text { RAL / DECLARACIONES CONJUNTAS / ANEXOS } \\
\text { (TiTULOS DE LOS ARTICULOS O APARTES) }\end{array}$ & $\begin{array}{l}\text { REFERENCIA A PRINCIPIOS Y DERECHOS FUNDAMENTALES } \\
\text { EN EL TRABAJO Y OTROS TEMAS } \\
\text { (TRANSCRIPCIÓN DE APARTES PERTINENTES) }\end{array}$ \\
\hline
\end{tabular}




\begin{tabular}{|c|c|c|c|}
\hline Paises Signatarios & 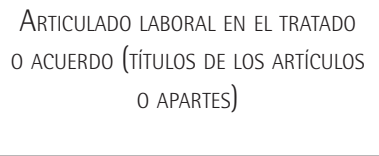 & $\begin{array}{l}\text { ACUERDOS COMPLEMENTARIOS / MEMORÁN- } \\
\text { DUMS / MECANISMOS DE COOPERACIÓN LABO- } \\
\text { RAL / DECLARACIONES CONJUNTAS / ANEXOS } \\
\text { (TitULLOS DE LOS ARTICULOS O APARTES) }\end{array}$ & $\begin{array}{c}\text { REFERENCIA A PRINCIPIOS Y DERECHOS FUNDAMENTALES } \\
\text { EN EL TRABAJO Y OTROS TEMAS } \\
\text { (TRANSCRIPCIÓN DE APARTES PERTINENTES) }\end{array}$ \\
\hline & & & $\begin{array}{l}\text { (a) Derechos fundamentales en el trabajo y su } \\
\text { aplicación efectiva: cooperación en legislación } \\
\text { y prácticas relacionadas a la implementación e } \\
\text { información pública de los principios y derechos } \\
\text { contenidos en la Declaración de la ort: (i) liber- } \\
\text { tad de asociación y reconocimiento efectivo del } \\
\text { derecho de negociación colectiva, (ii) elimina- } \\
\text { ción de todas las formas de trabajo forzoso u } \\
\text { obligatorio, (iii) la abolición efectiva del trabajo } \\
\text { infantil, y (iv) la eliminación de la discriminación } \\
\text { en materia de empleo y ocupación. } \\
\text { (b) Peores formas de trabajo infantil: programas } \\
\text { u otras formas de cooperación para promover el } \\
\text { cumplimiento del Convenio 182 de la oit sobre } \\
\text { la Prohibición y Acción Inmediata para la Elimi- } \\
\text { nación de las Peores Formas de Trabajo Infantil. } \\
\text { (c) Administración laboral: actividades dirigidas } \\
\text { al fortalecimiento de la capacidad institucional } \\
\text { de las administraciones laborales y tribunales la- } \\
\text { borales, especialmente profesionalización de los } \\
\text { recursos humanos y capacitación, incluyendo en } \\
\text { materia de capacidad tecnológica. } \\
\text { (d) Inspección laboral: actividades para mejorar } \\
\text { la aplicación y cumplimiento de la legislación la- } \\
\text { boral, incluyendo capacitación e iniciativas para }\end{array}$ \\
\hline
\end{tabular}




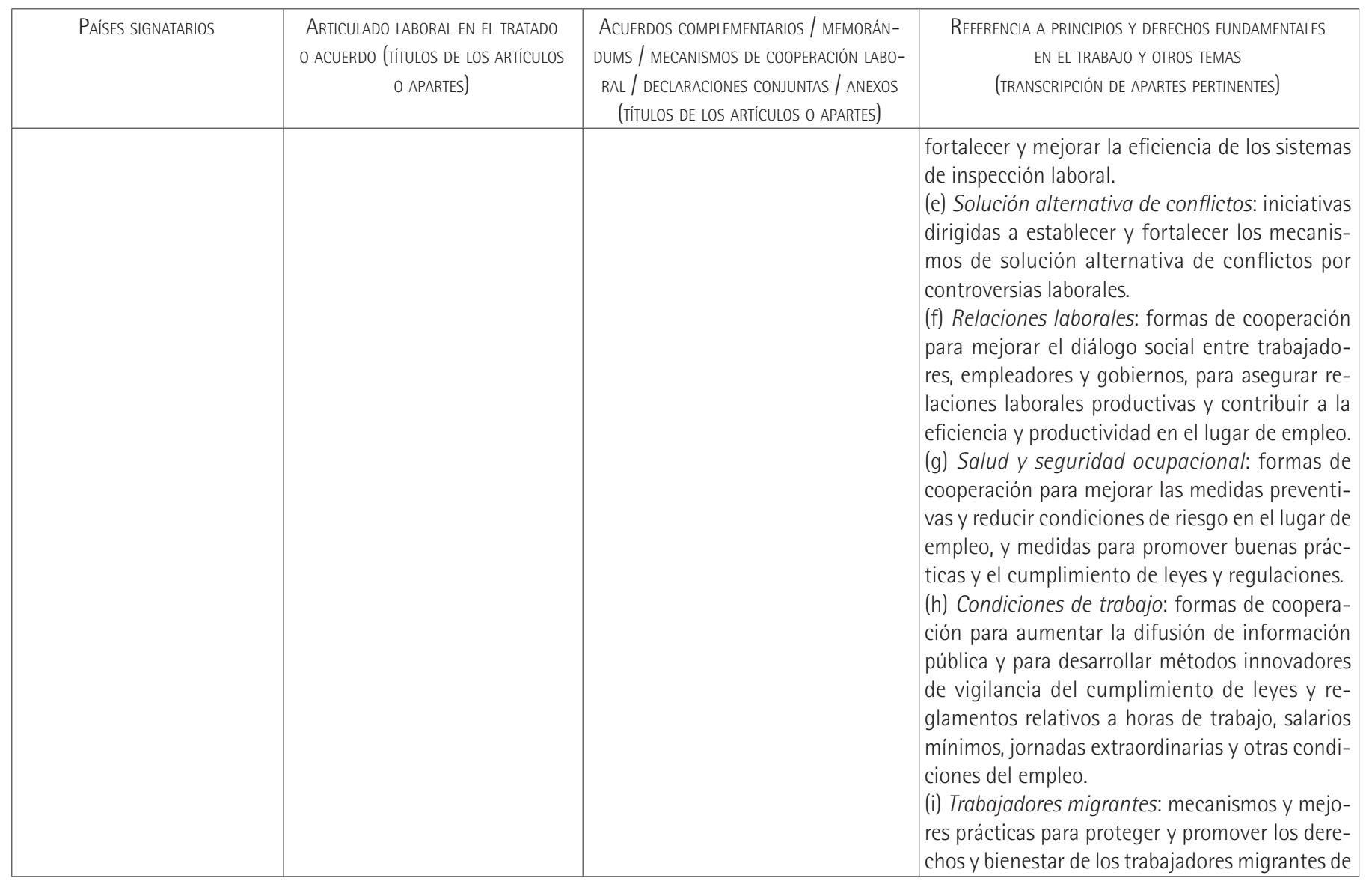




\begin{tabular}{|c|c|c|c|}
\hline PAISES SIGNATARIOS & 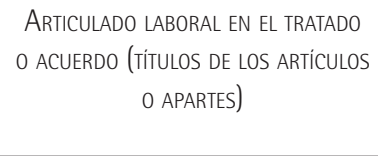 & $\begin{array}{l}\text { ACUERDOS COMPLEMENTARIOS / MEMORÁN- } \\
\text { DUMS / MECANISMOS DE COOPERACIÓN LABO- } \\
\text { RAL / DECLARACIONES CONJUNTAS / ANEXOS } \\
\text { (TitULLOS DE LOS ARTICULOS O APARTES) }\end{array}$ & $\begin{array}{c}\text { REFERENCIA A PRINCIPIOS Y DERECHOS FUNDAMENTALES } \\
\text { EN EL TRABAJO Y OTROS TEMAS } \\
\text { (TRANSCRIPCIÓN DE APARTES PERTINENTES) }\end{array}$ \\
\hline & & & $\begin{array}{l}\text { las Partes, incluyendo esfuerzos conjuntos con } \\
\text { organizaciones relevantes, y difusión de infor- } \\
\text { mación respecto a los derechos laborales de los } \\
\text { trabajadores migrantes en el territorio de cada } \\
\text { una de las Partes. } \\
\text { (j) Asistencia social y capacitación: programas } \\
\text { de asistencia social, desarrollo de recursos hu- } \\
\text { manos, capacitación y reconversión laboral, así } \\
\text { como otros programas relevantes. } \\
\text { (k) Intercambio de tecnología e información: } \\
\text { programas para intercambiar información y } \\
\text { compartir experiencias sobre métodos para me- } \\
\text { jorar la productividad, sobre la promoción de } \\
\text { buenas prácticas laborales y sobre el uso efectivo } \\
\text { de tecnologias, incluyendo aquellas que se basan } \\
\text { en la Internet. } \\
\text { (I) Estadisticas laborales: desarrollo de métodos } \\
\text { para que las Partes generen estadisticas compa- } \\
\text { rables del mercado laboral en forma oportuna, } \\
\text { incluyendo el mejoramiento de los sistemas de } \\
\text { recolección de datos. } \\
\text { (m) Oportunidades de empleo: desarrollo de pro- } \\
\text { gramas para la promoción de nuevas oportuni- } \\
\text { dades de empleo y modernización de la mano de } \\
\text { obra, incluyendo servicios de empleo. }\end{array}$ \\
\hline
\end{tabular}




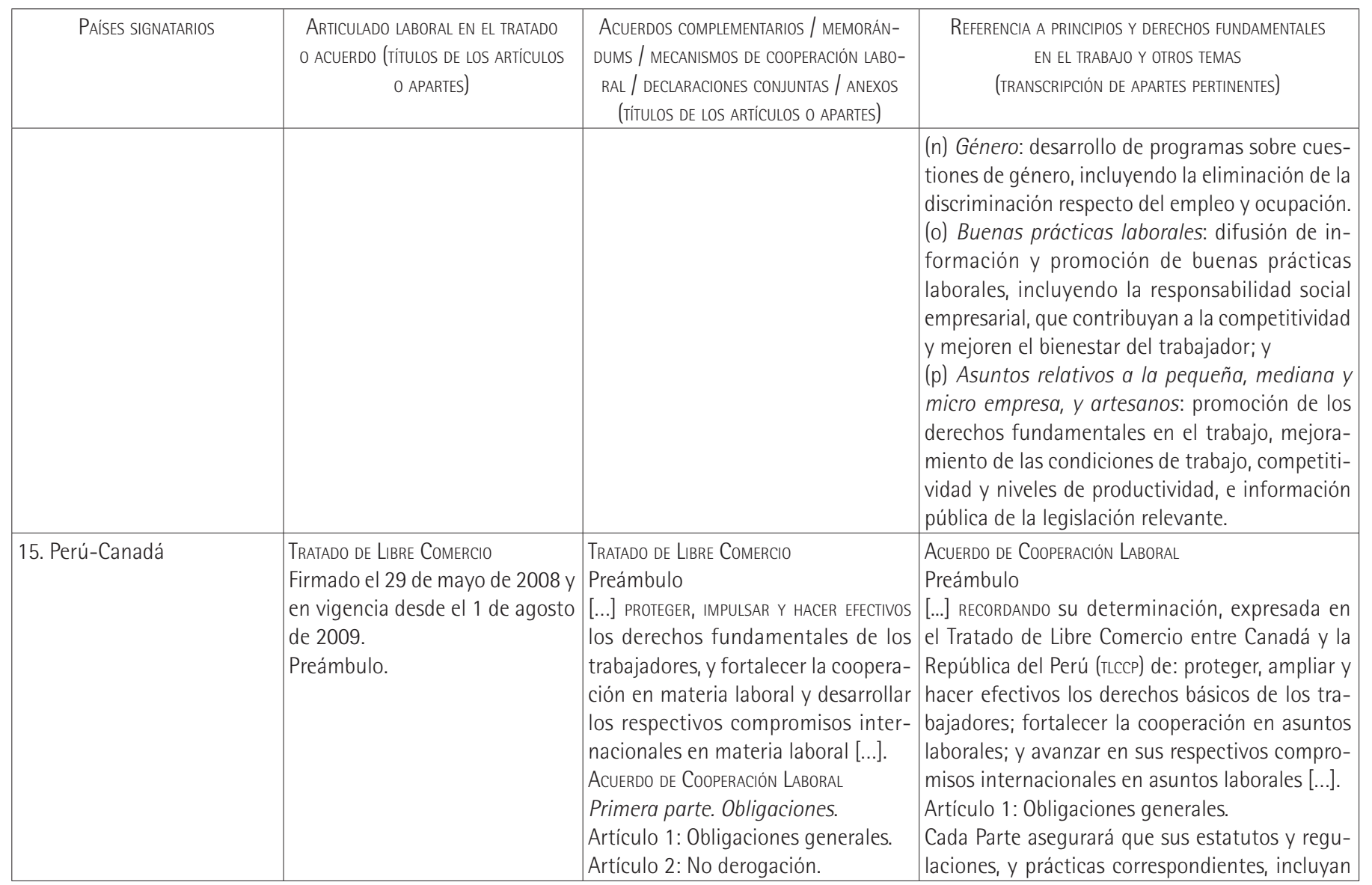




\begin{tabular}{|c|c|c|c|}
\hline PaISES SIGNATARIOS & 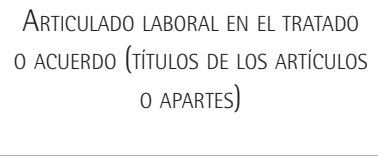 & $\begin{array}{l}\text { ACUERDOS COMPLEMENTARIOS / MEMORÁN- } \\
\text { DUMS / MECANISMOS DE COOPERACIÓN LABO- } \\
\text { RAL / DECLARACIONES CONJUNTAS / ANEXOS } \\
\text { (TítULOS DE LOS ARTICULOS O APARTES) }\end{array}$ & $\begin{array}{c}\text { REFERENCIA A PRINCIPIOS Y DERECHOS FUNDAMENTALES } \\
\text { EN EL TRABAJO Y OTROS TEMAS } \\
\text { (TRANSCRIPCIÓN DE APARTES PERTINENTES) }\end{array}$ \\
\hline & & $\begin{array}{l}\text { Artículo 3: Medidas gubernamenta- } \\
\text { les para la aplicación efectiva de la } \\
\text { legislación laboral. } \\
\text { Artículo 4: Acceso de los particulares } \\
\text { a los procedimientos. } \\
\text { Artículo 5: Garantías procesales. } \\
\text { Artículo 6: Información y conoci- } \\
\text { miento públicos. } \\
\text { Segunda parte. Mecanismos institu- } \\
\text { cionales. } \\
\text { Artículo 7: Consejo Ministerial. } \\
\text { Artículo 8: Mecanismos nacionales. } \\
\text { Artículo 9: Actividades de coopera- } \\
\text { ción. } \\
\text { Artículo 10: Comunicaciones del pú- } \\
\text { blico. } \\
\text { Artículo 11: Consultas generales. } \\
\text { Tercera parte. Procedimiento de revi- } \\
\text { sión de obligaciones. } \\
\text { Artículo 12: Consultas ministeriales. } \\
\text { Articulo 13: Panel de revisión. } \\
\text { Artículo 14: Panelistas. } \\
\text { Artículo 15: Conducción de una re- } \\
\text { visión. } \\
\text { Artículo 16: Información para el pa- } \\
\text { nel de revisión. }\end{array}$ & $\begin{array}{l}\text { los siguientes principios y derechos laborales } \\
\text { reconocidos a nivel internacional y les brinden } \\
\text { protección: } \\
\text { a. La libertad de asociación y el derecho a nego- } \\
\text { ciar en forma colectiva (incluyendo la protec- } \\
\text { ción del derecho a organizarse y el derecho de } \\
\text { huelga); } \\
\text { b. La eliminación de toda forma de trabajo for- } \\
\text { zado u obligatorio; } \\
\text { c. La abolición efectiva del trabajo infantil (inclu- } \\
\text { yendo protección a los niños y jóvenes); } \\
\text { d. La eliminación de la discriminación respecto al } \\
\text { empleo y la ocupación; } \\
\text { e. Condiciones aceptables de trabajo con respec- } \\
\text { to a salarios mínimos, horas de trabajo y seguri- } \\
\text { dad y salud en el trabajo; y, } \\
\text { f. Proporcionar a los trabajadores migrantes la } \\
\text { misma protección legal que a sus nacionales, } \\
\text { respecto a las condiciones de trabajo. }\end{array}$ \\
\hline
\end{tabular}




\begin{tabular}{|c|c|c|c|}
\hline PAises SIGNATARIOS & 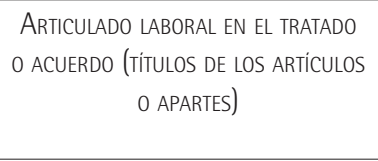 & $\begin{array}{l}\text { ACUERDOS COMPLEMENTARIOS / MEMORÁN- } \\
\text { DUMS / MECANISMOS DE COOPERACIÓN LABO- } \\
\text { RAL / DECLARACIONES CONJUNTAS / ANEXOS } \\
\text { (TitULOS DE LOS ARTICULOS O APARTES) }\end{array}$ & $\begin{array}{c}\text { REFERENCIA A PRINCIPIOS Y DERECHOS FUNDAMENTALES } \\
\text { EN EL TRABAJO Y OTROS TEMAS } \\
\text { (TRANSCRIPCIÓN DE APARTES PERTINENTES) }\end{array}$ \\
\hline & & $\begin{array}{l}\text { Artículo 17: Informe preliminar. } \\
\text { Artículo 18: Informe final. } \\
\text { Artículo 19: Cumplimiento del infor- } \\
\text { me final. } \\
\text { Artículo 20: Revisión de la imple- } \\
\text { mentación. } \\
\text { Artículo 21: Revisión de cumpli- } \\
\text { miento. } \\
\text { Cuarta parte. Condiciones generales. } \\
\text { Artículo 22: Principio para la aplica- } \\
\text { ción de la legislación laboral. } \\
\text { Artículo 23: Derechos de particu- } \\
\text { lares. } \\
\text { Artículo 24: Protección de informa- } \\
\text { ción. } \\
\text { Artículo 25: Cooperación con orga- } \\
\text { nismos internacionales y regionales. } \\
\text { Artículo 26: Definiciones. } \\
\text { Quinta parte. Disposiciones finales. } \\
\text { Anexo 1. Actividades de cooperación. } \\
\text { Anexo 2. Comunicaciones del pú- } \\
\text { blico. } \\
\text { Anexo 3. Procedimientos relaciona- } \\
\text { dos con los paneles de revisión. } \\
\text { Anexo 4. Contribuciones monetarias. } \\
\text { Anexo 5. Extensión de las obligacio- } \\
\text { nes. }\end{array}$ & \\
\hline
\end{tabular}




\begin{tabular}{|c|c|c|c|}
\hline Paises Signatarios & 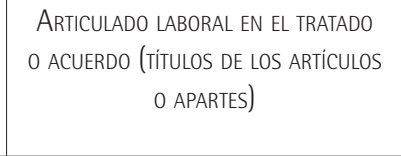 & $\begin{array}{l}\text { ACUERDOS COMPLEMENTARIOS / MEMORÁN- } \\
\text { DUMS / MECANISMOS DE COOPERACIÓN LABO- } \\
\text { RAL / DECLARACIONES CONJUNTAS / ANEXOS } \\
\text { (TiTULOS DE LOS ARTiCULOS O APARTES) }\end{array}$ & $\begin{array}{c}\text { REFERENCIA A PRINCIPIOS Y DERECHOS FUNDAMENTALES } \\
\text { EN EL TRABAJO Y OTROS TEMAS } \\
\text { (TRANSCRIPCIÓN DE APARTES PERTINENTES) }\end{array}$ \\
\hline $\begin{array}{l}\text { 17. República Dominicana, } \\
\text { Estados Unidos y Centro } \\
\text { América (Costa Rica, El Sal- } \\
\text { vador, Guatemala, Honduras } \\
\text { y Nicaragua) (CAFrA) }\end{array}$ & $\begin{array}{l}\text { Tratado DE Libre Comercio } \\
\text { Firmado el } 5 \text { de agosto de } 2005 \\
\text { y en vigencia desde el } 1 \text { de mar- } \\
\text { zo de } 2006 \text { (El Salvador y Esta- } \\
\text { dos Unidos), } 1 \text { de abril de } 2006 \\
\text { (Honduras y Nicaragua), } 1 \text { de }\end{array}$ & $\begin{array}{l}\text { ANEXO 16.5. MECANISMO DE COOPERACIÓN } \\
\text { LABORAL Y DESARROLLO DE CAPACIDADES } \\
\text { Organización y funciones principa- } \\
\text { les. } \\
\text { Prioridades de cooperación y desa- } \\
\text { rrollo de capacidades. }\end{array}$ & $\begin{array}{l}\text { CAPITULO DIECISÉIS (LABORAL) } \\
\text { Artículo 16.1: Declaración de compromisos com- } \\
\text { partidos. } \\
\text { 1. Las Partes reafirman sus obligaciones como } \\
\text { miembros de la Organización Internacional del } \\
\text { Trabajo (oIT) y sus compromisos asumidos en vir- }\end{array}$ \\
\hline
\end{tabular}




\begin{tabular}{|c|c|c|c|}
\hline Paises Signatarios & 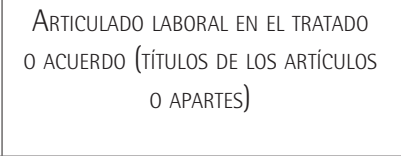 & $\begin{array}{l}\text { ACUERDOS COMPLEMENTARIOS / MEMORÁN- } \\
\text { DUMS / MECANISMOS DE COOPERACIÓN LABO- } \\
\text { RAL / DECLARACIONES CONJUNTAS / ANEXOS } \\
\text { (TiTULOS DE LOS ARTICULOS O APARTES) }\end{array}$ & $\begin{array}{c}\text { REFERENCIA A PRINCIPIOS Y DERECHOS FUNDAMENTALES } \\
\text { EN EL TRABAJO Y OTROS TEMAS } \\
\text { (TRANSCRIPCIÓN DE APARTES PERTINENTES) }\end{array}$ \\
\hline
\end{tabular}




\begin{tabular}{|c|c|c|c|}
\hline Paises Signatarios & 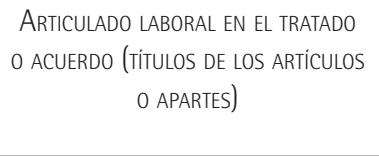 & $\begin{array}{l}\text { ACUERDOS COMPLEMENTARIOS / MEMORÁN- } \\
\text { DUMS / MECANISMOS DE COOPERACIÓN LABO- } \\
\text { RAL / DECLARACIONES CONJUNTAS / ANEXOS } \\
\text { (TitULLOS DE LOS ARTICULOS O APARTES) }\end{array}$ & $\begin{array}{l}\text { REFERENCIA A PRINCIPIOS Y DERECHOS FUNDAMENTALES } \\
\text { EN EL TRABAJO Y OTROS TEMAS } \\
\text { (TRANSCRIPCIÓN DE APARTES PERTINENTES) }\end{array}$ \\
\hline & & & $\begin{array}{l}\text { derecho de organizarse y negociar colectivamen- } \\
\text { te; (c) la prohibición del uso de cualquier forma } \\
\text { de trabajo forzoso u obligatorio; (d) una edad } \\
\text { mínima para el empleo de niños, y la prohibición } \\
\text { y eliminación de las peores formas de trabajo } \\
\text { infantil, y (e) condiciones aceptables de trabajo } \\
\text { respecto a salarios mínimos, horas de trabajo y } \\
\text { seguridad y salud ocupacional. } \\
\text { AnEXo 16.5. MECANISMo DE coopeRAción LABORAL y DESA- } \\
\text { RRoLLo DE CAPACIDADES } \\
\text { [...] 3. El Mecanismo podrá iniciar actividades de } \\
\text { cooperación bilateral o regional en temas labo- } \\
\text { rales, que podrán incluir, pero no limitándose a: } \\
\text { (a) derechos fundamentales y su efectiva aplica- } \\
\text { ción: legislación y su implementación relaciona- } \\
\text { da con los elementos básicos de la Declaración } \\
\text { de la oit (libertad de asociación y el reconoci- } \\
\text { miento efectivo del derecho de negociación } \\
\text { colectiva, la prohibición del uso de cualquier } \\
\text { forma de trabajo forzoso u obligatorio, abolición } \\
\text { efectiva del trabajo infantil y la eliminación de la } \\
\text { discriminación en el empleo y la ocupación); (b) } \\
\text { peores formas de trabajo infantil: legislación y su } \\
\text { implementación relacionada con el cumplimien- } \\
\text { to de la Convención } 182 \text { de la olt [...]. }\end{array}$ \\
\hline
\end{tabular}




\begin{tabular}{|c|c|c|c|}
\hline Países SIgnatarios & $\begin{array}{c}\text { ARTiculado LABORAL EN EL TRATAdO } \\
\text { 0 ACUERDO (TitulOS DE LOS ARTíCULOS } \\
\text { 0 APARTES) }\end{array}$ & $\begin{array}{l}\text { ACUERDOS COMPLEMENTARIOS / MEMORÁN- } \\
\text { DUMS / MECANISMOS DE COOPERACIÓN LABO- } \\
\text { RAL / DECLARACIONES CONJUNTAS / ANEXOS } \\
\text { (TiTULOS DE LOS ARTICULOS O APARTES) }\end{array}$ & $\begin{array}{c}\text { REFERENCIA A PRINCIPIOS Y DERECHOS FUNDAMENTALES } \\
\text { EN EL TRABAJO Y OTROS TEMAS } \\
\text { (TRANSCRIPCIÓN DE APARTES PERTINENTES) }\end{array}$ \\
\hline $\begin{array}{l}\text { 18. CARIFORUM } \\
\text { Integrado por República Do- } \\
\text { minicana, } 14 \text { países más* y la } \\
\text { Comunidad Europea. }\end{array}$ & $\begin{array}{l}\text { ACUERDO DE AsOCIACIÓn ECONÓmicA } \\
\text { Firmado el } 15 \text { de octubre de } \\
2008 \text { y en vigencia provisional } \\
\text { desde el } 29 \text { de diciembre de } \\
2008 . \\
\text { Capítulo } 5 \text { (Aspectos sociales). } \\
\text { Artículo 191: Objetivos y com- } \\
\text { promisos multilaterales. } \\
\text { Artículo 192: Niveles de protec- } \\
\text { ción y derecho a regular. } \\
\text { Artículo 193: Mantenimiento de } \\
\text { los niveles de protección. } \\
\text { Artículo 194: Integración regio- } \\
\text { nal. } \\
\text { Artículo 195: Proceso de consul- } \\
\text { ta y seguimiento. } \\
\text { Artículo 196: Cooperación. }\end{array}$ & & $\begin{array}{l}\text { CAPítulo } 5 \text { (AsPECTOS SOCIALES) } \\
\text { Artículo 191: Objetivos y compromisos multila- } \\
\text { terales. } \\
\text { 1. Las Partes reafirman su compromiso con las } \\
\text { normas fundamentales de trabajo reconocidas } \\
\text { a nivel internacional, tal como se definen en los } \\
\text { correspondientes convenios de la olt, en parti- } \\
\text { cular sobre libertad de asociación y derecho de } \\
\text { negociación colectiva, abolición del trabajo for- } \\
\text { zado, eliminación de las peores formas de tra- } \\
\text { bajo infantil y no discriminación en materia de } \\
\text { empleo. Las Partes también reafirman sus obliga- } \\
\text { ciones como miembros de la oit y sus compromi- } \\
\text { sos en virtud de la Declaración de la olt relativa } \\
\text { a los Principios y Derechos Fundamentales en el } \\
\text { Trabajo y su Seguimiento (1998) [...]. }\end{array}$ \\
\hline
\end{tabular}

FUENTE: http://www.sice.oas.org/agreements_s.asp.

* Antigua y Barbuda, Commonwealth de las Bahamas, Barbados, Belice, Commonwealth de Dominica, Granada, República Cooperativa de Guyana, República de Haití, Jamaica, San Cristóbal y Nieves, Santa Lucía, San Vicente y las Granadinas, República de Surinam, República de Trinidad y Tobago. 